\title{
المؤثرات التربوية الإيجابية والسلبية \\ في سورة محمد (صلى الله عليه وسلم)
}

\author{
إعـــــلـداد \\ ه. عبد العزيز بــ عبد الرحمــ الحيميد \\ أستاذ التربية الإسلامية المشارك

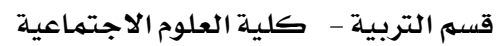 \\ جامعة الإمام محمد بن سعود الإسلامية - الرياض
}

مجلة بحوث التربية النوعية - جامعة المنصورة

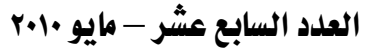




\section{المؤثرات التزبوية الإيجابية والسلبية}

\section{في سورة همد (صلى الاله عليه وسلم)}

$$
\text { إعـداد }
$$

د. عبد العزيز نزعبد الرحمزالمحيميد

\section{|lلصف}

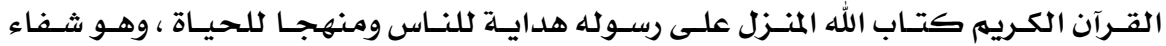

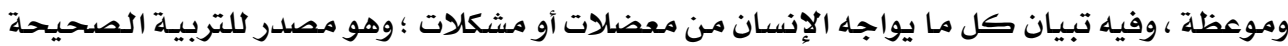

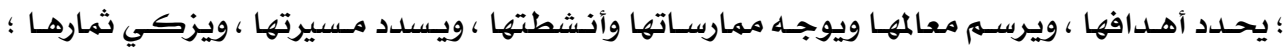

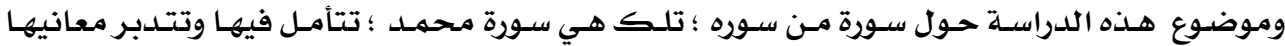

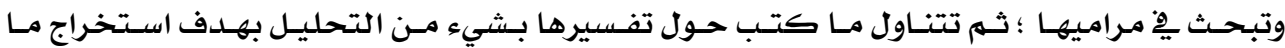

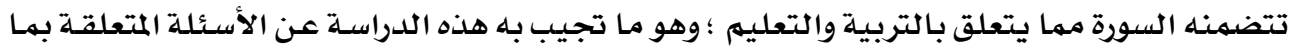

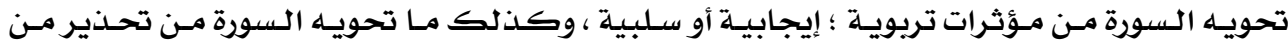

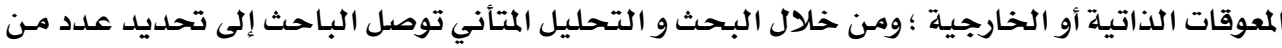

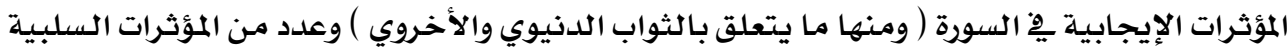

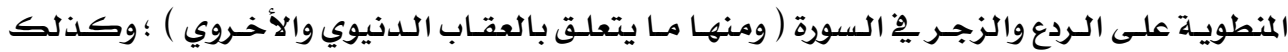

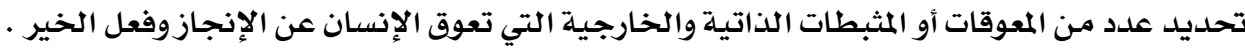




\section{المؤثرات التزبوية الإيجابية والسلبية \\ في سورة هحمد (صلى الاله عليه وسلم)}

إعــداد

د. عبد العزيز نغعبد الرحمنالخحيميد

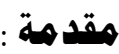

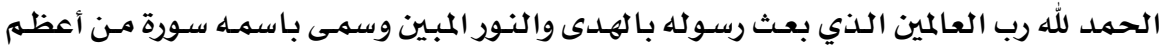

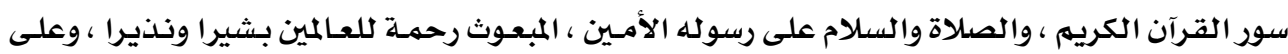

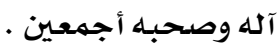

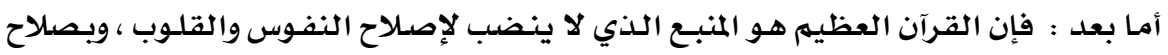

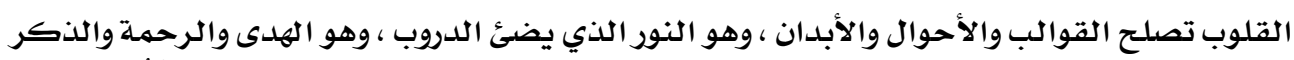

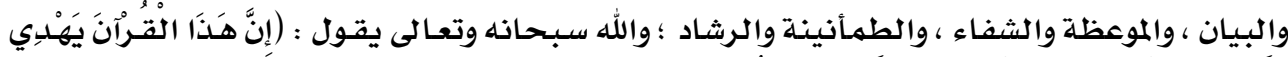

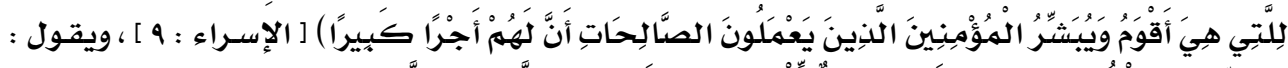

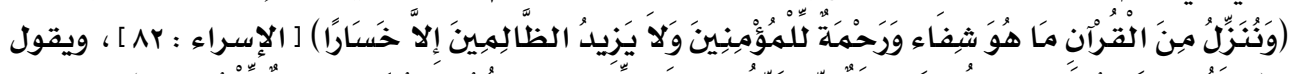

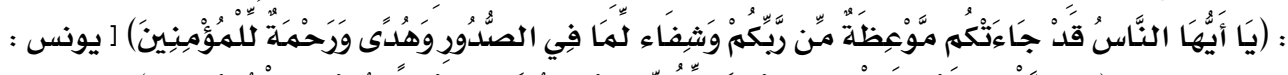

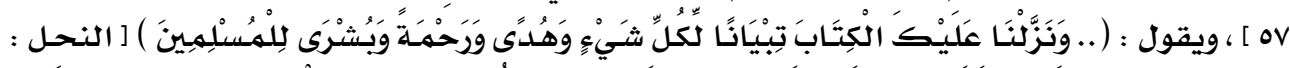

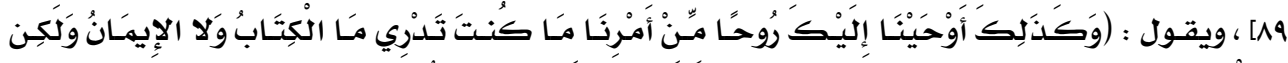

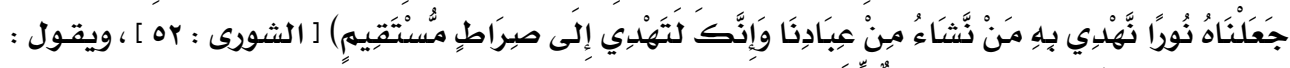

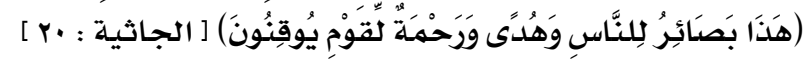

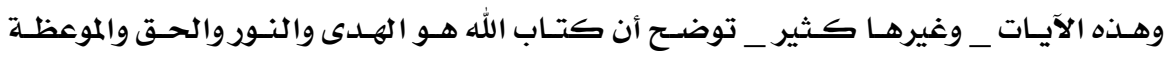

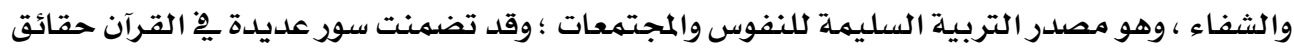

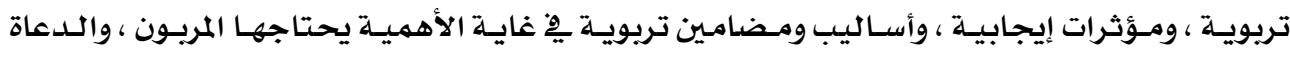

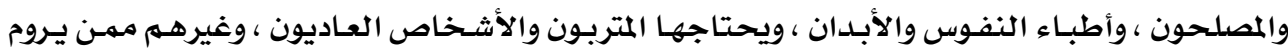

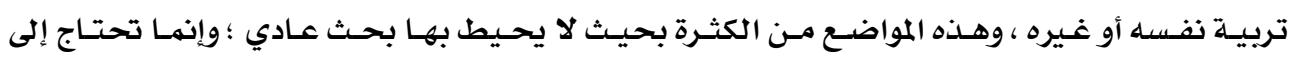

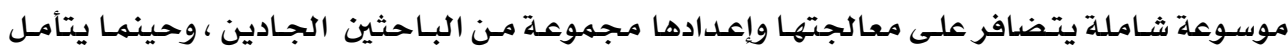

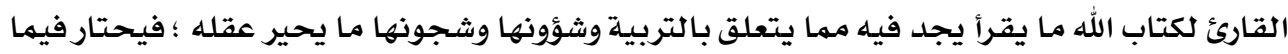

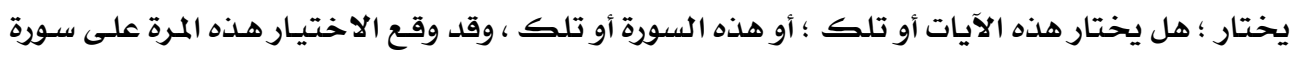

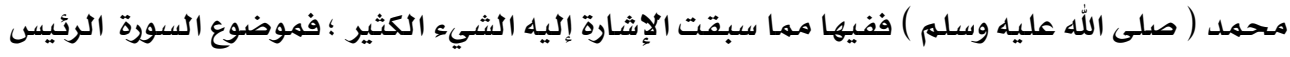

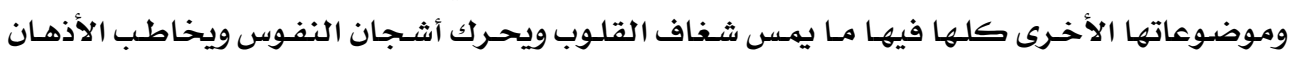

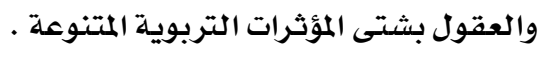


وانطلاقا من ذلك كلله فإن موضوع هذه الدراسـة هو المؤثرات التربويـة الإيجابيـة والسلبيـة ،

وكذلك معوقات السلوك ِِّ سورة محمد ( صلى الله عليه وسلهم ) .

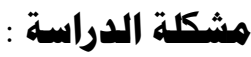

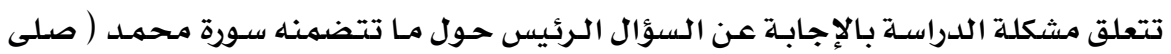

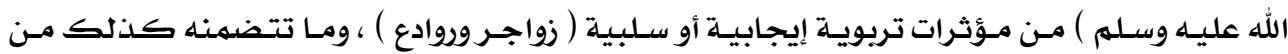

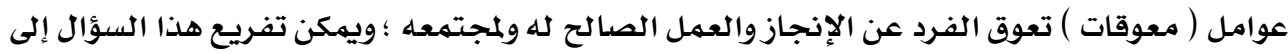

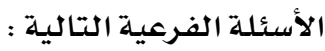

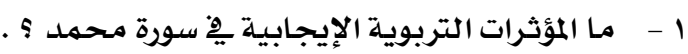

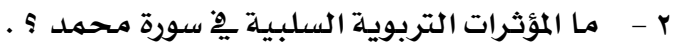

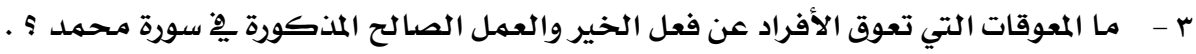

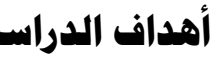

تتمثل أهداف الدراسـة يِّ الكشف عن المؤثرات التربوية الإيجابية والسلبية ومعوقات السلوك

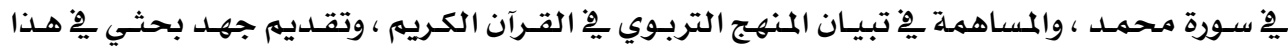

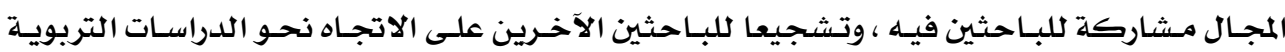

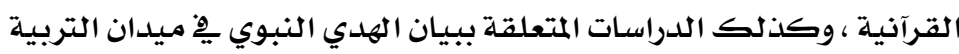

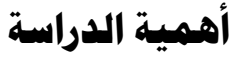

تنبثثق أهمية الدراسـة مـن أهميـة موضـوعها ذاتـه ؛ فهي تهـدف إلى اسـتجلاء بعض المضامين

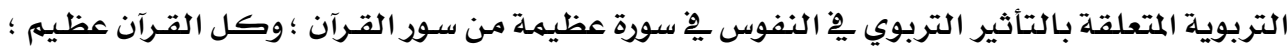

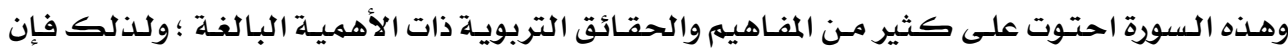
دراسـة هذه الحقائق وإبرازها من خلال هذه السورة العظيمـة له أهمية بحثية وعلمية كبرية كبيرة .

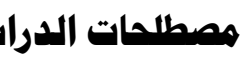

•

التربيـة المقصودة ِِِ هـذه الدراسـة هي التربيـة الإسـلامية ؛وهـي كمها يعرفها صـالح أحمـد

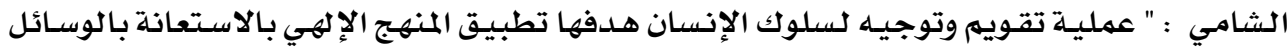

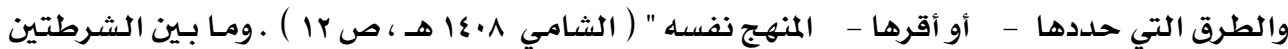
من تصرف الباحث .

• المضموز التربوي :

هو ما تتضمنه سورة محمد وتحتويه من مؤثرات ومفاهيه وحقائق وتوجيهات تربويـة نظرية وتطبيقية .

• الحوافز : 


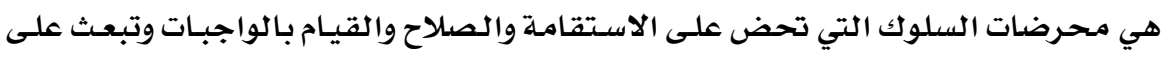

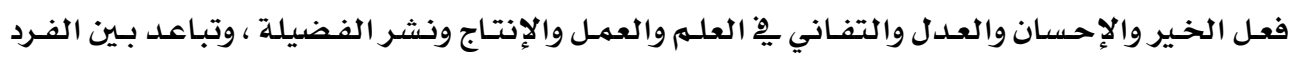

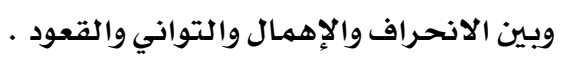

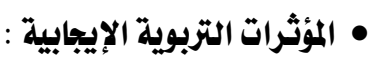

هي حوافزومحرضـات للسلوك تعتمـد على جـذب الفرد نحو الفعل المرغوب ( وترك الفعل

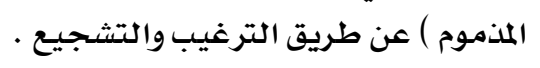

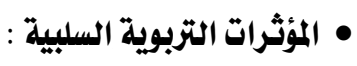

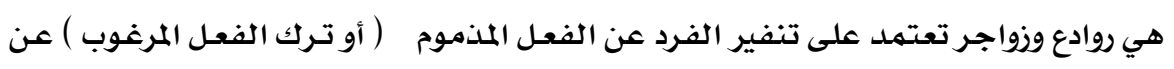
طريق الردع والزجر · موادعاج

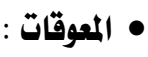

هي مـا يعـوق الفـرد عن فعل الخـير ؛ سـواء كانت معوقـا خارجيـا أو معوقـا ذاتيـا نفسيا ( مثبطات ) .

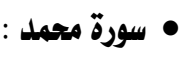

هي السورة المعروفة بهذا الاسم ، والمعروفة كذلك باسهم سورة القتال .

• منهج الدراسة : مي السرة

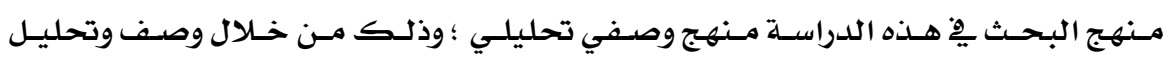

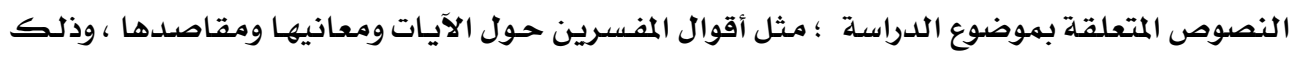

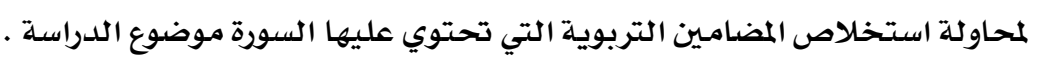

الدراسات السابقة :

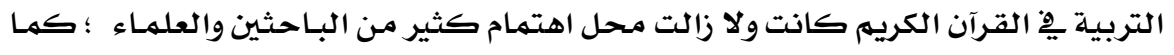

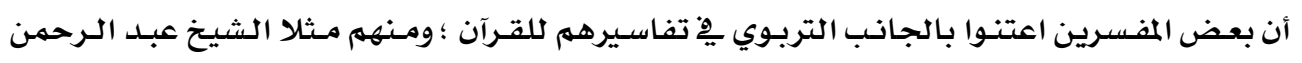

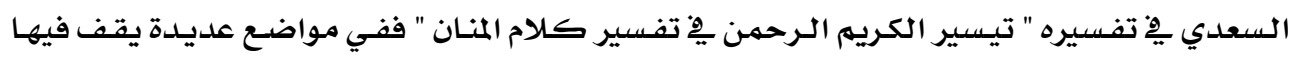

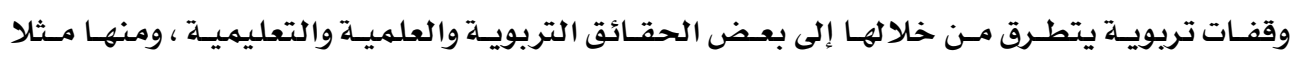

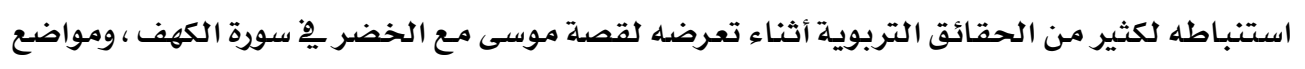
أخرى • وكذذك بعض المفسرين من المتقدمين والمعاصرين الذين اعتنوا بهذا الجانب .

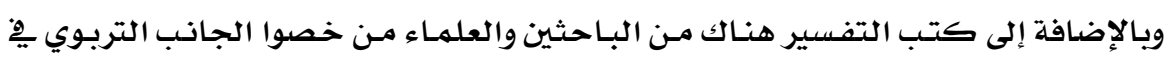

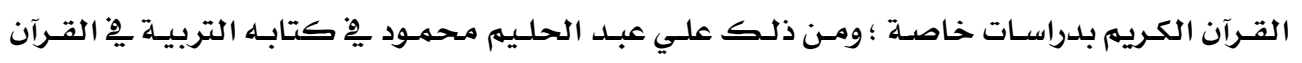

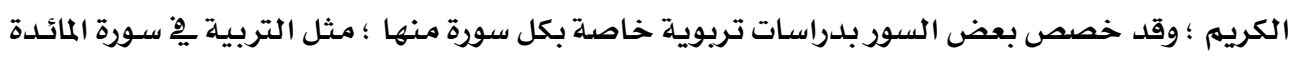

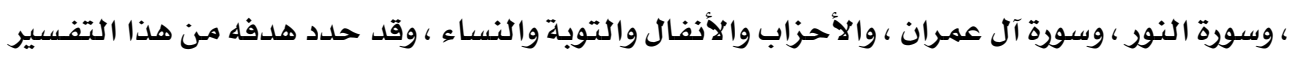

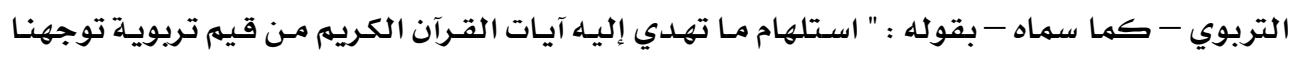

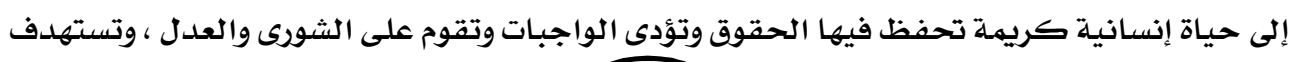




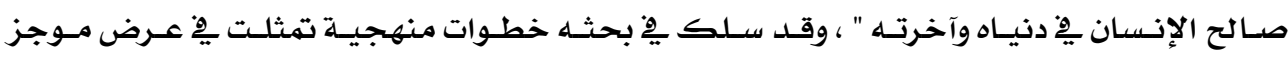

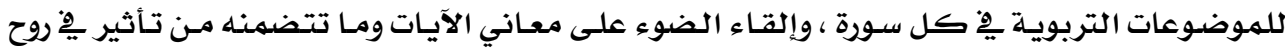

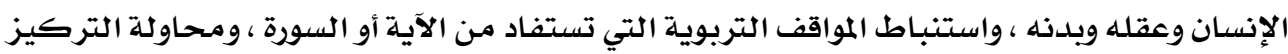

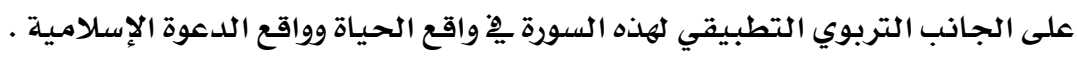

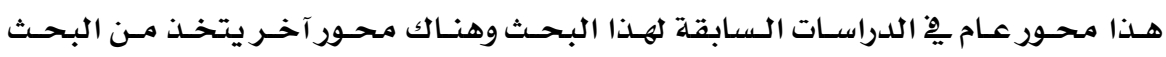

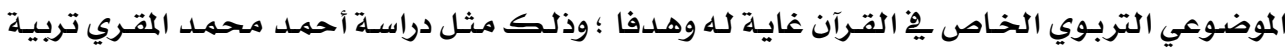

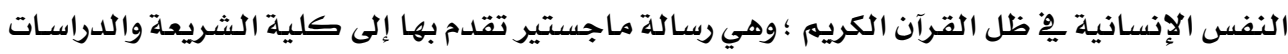

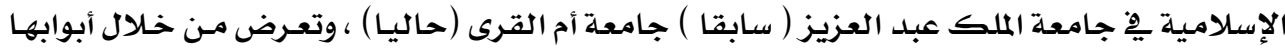

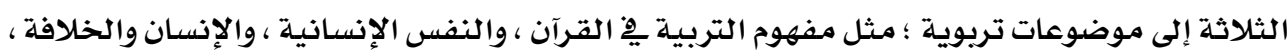

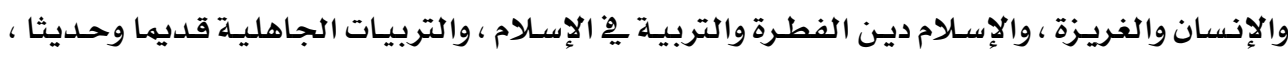

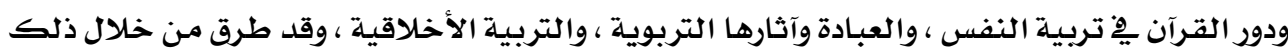
تفصيلات عديدة.

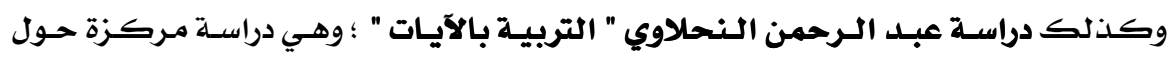

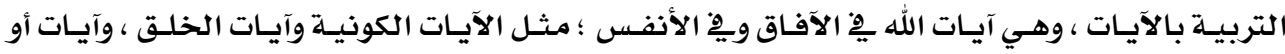

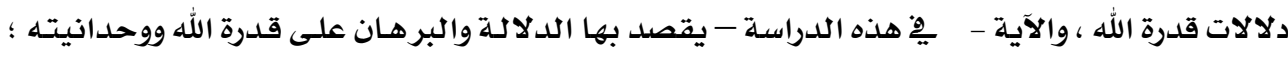

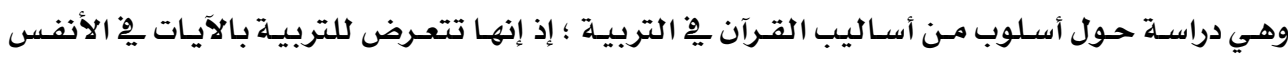

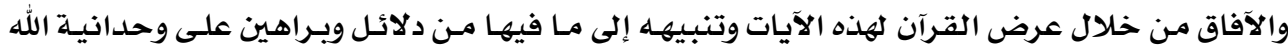

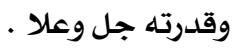

وهناك دراسة متخصصة بعنوان " أساليب التشويق والتعزيز بِ القرآن الكريم " وهي رسالة

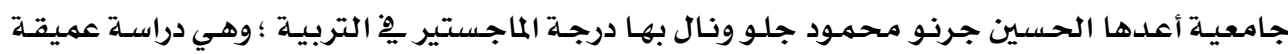

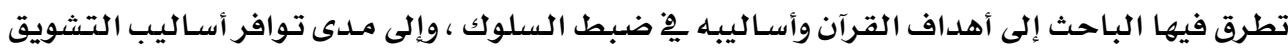

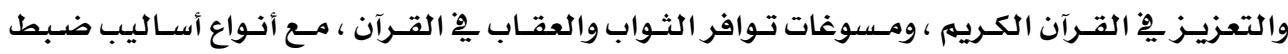

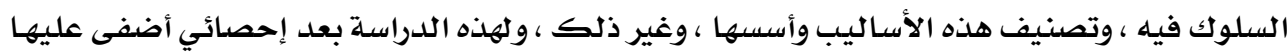

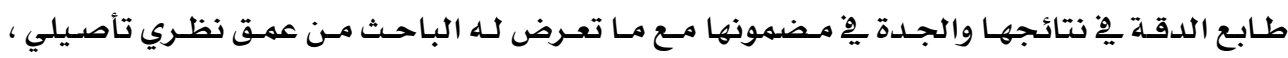

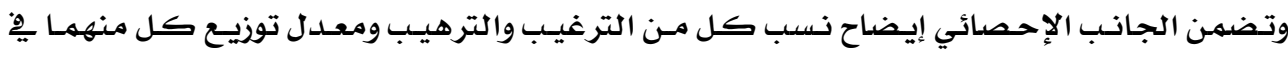

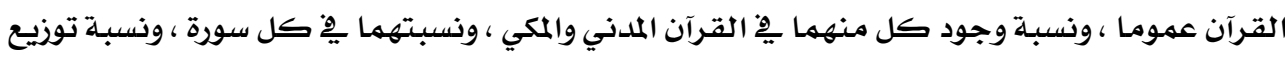

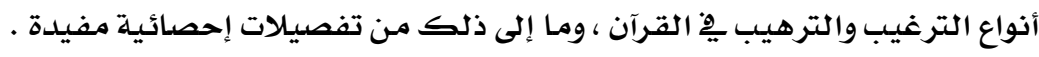
هناقشة الدراسات السابقة :

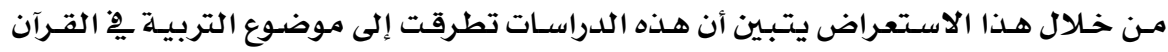

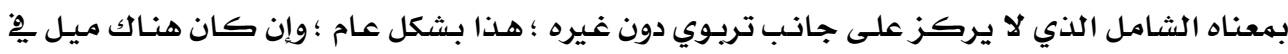

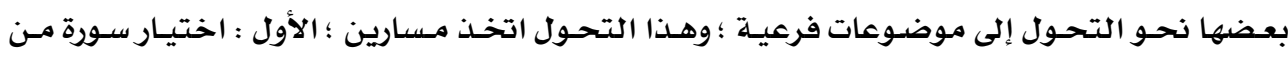

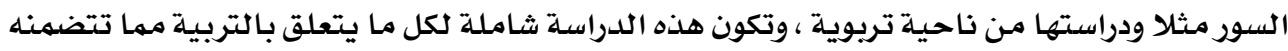




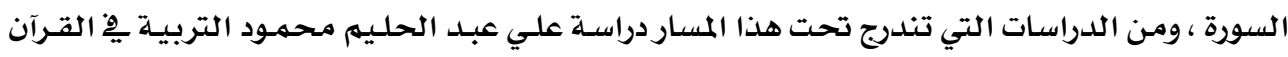

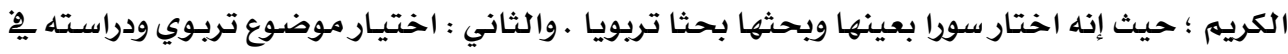

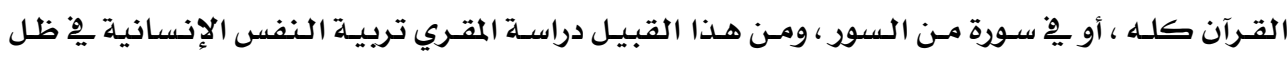

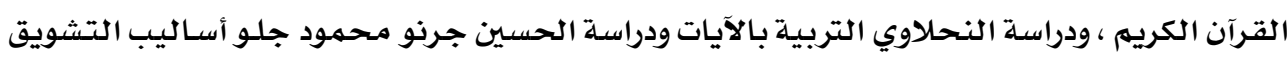

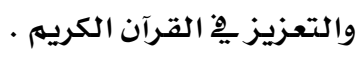

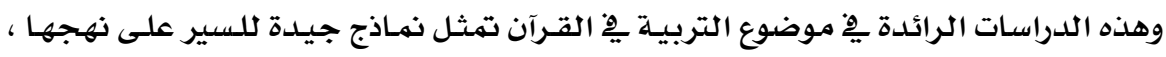

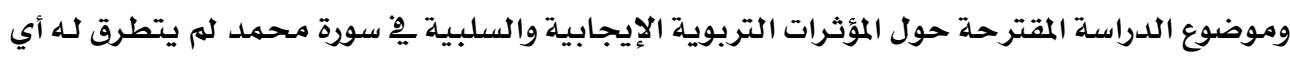

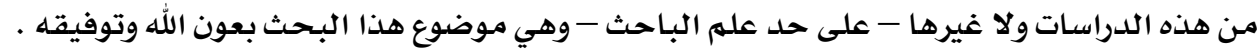

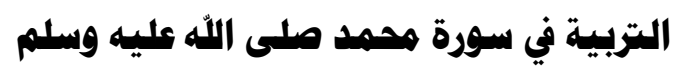

السورة وموضوعها :

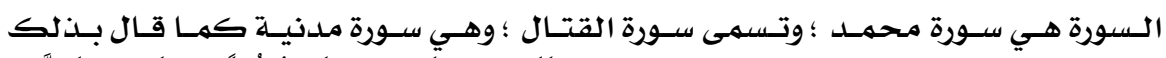

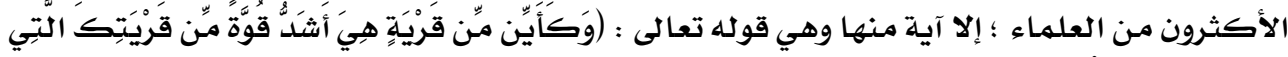

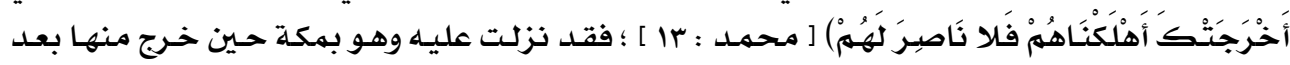

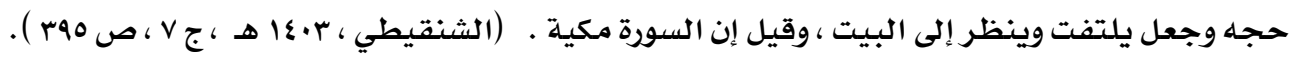

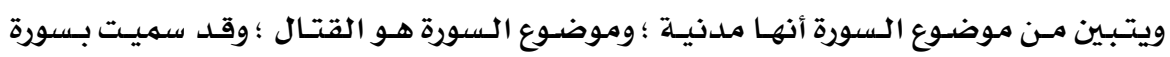

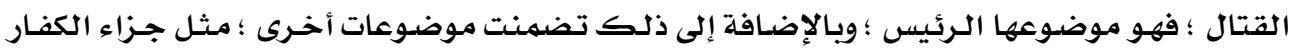

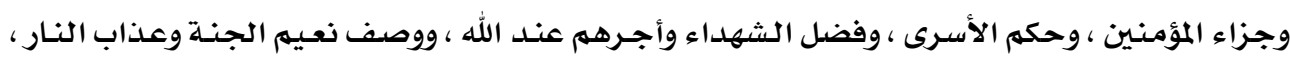

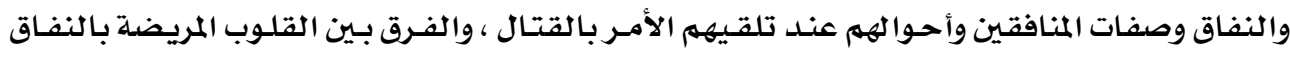

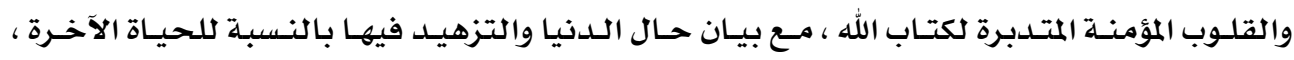

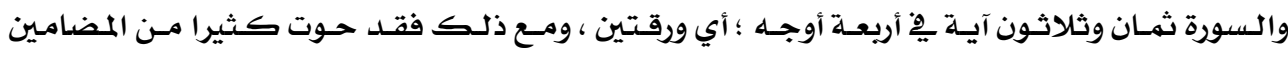

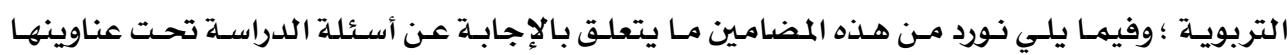

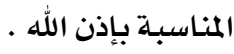

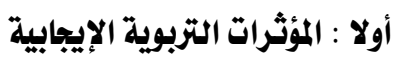

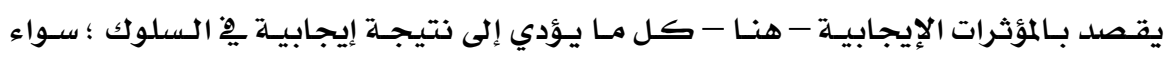

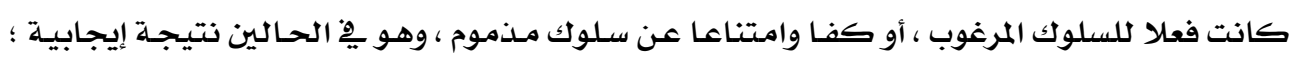

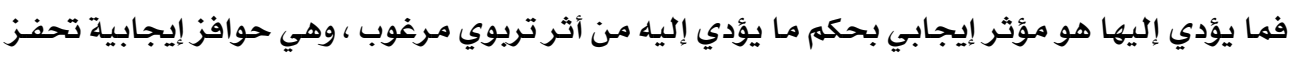

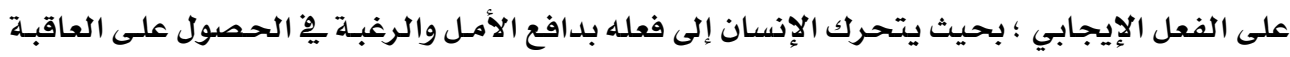

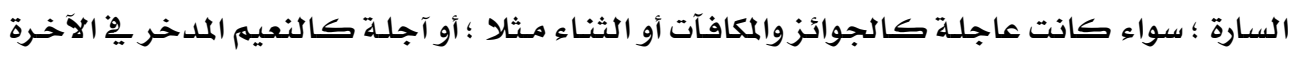

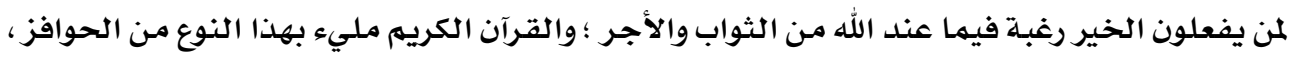

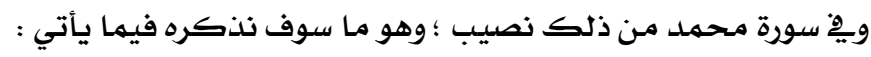


: الإبيمان

الإيهـان هـو أقـوى الحـوافز التربويــة الإســلاميـة ؛وهـو أقـوى الحـوافز الذاتيــة ؛ حيـث ينـدفع

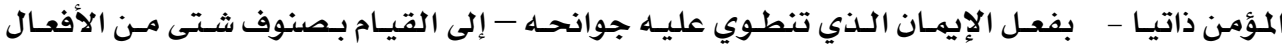

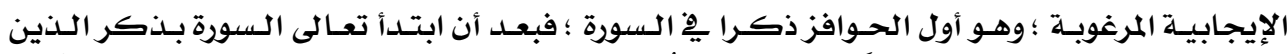

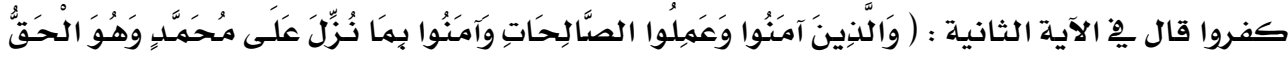

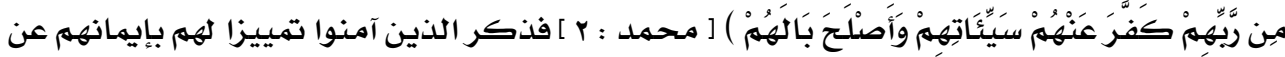

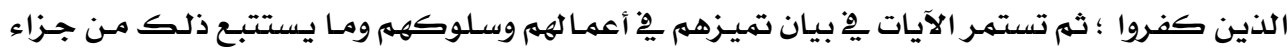

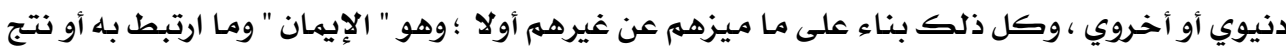

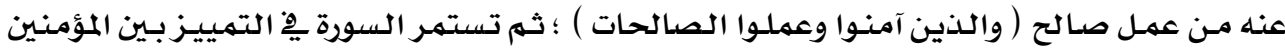

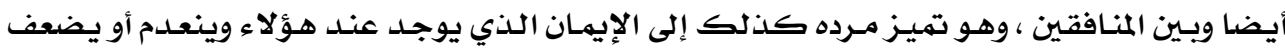

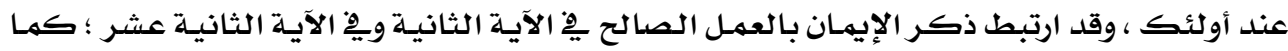

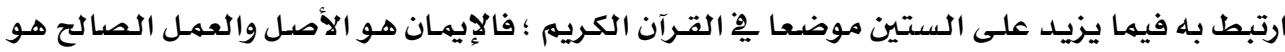
النتيجة المنبثقة عن ذلك الأصل ، والإيهان هو الحافز ، والعمل الصالح هو الثمرة المحفوزة بالإيمان .

: r - r النداء بصفة الإيمان

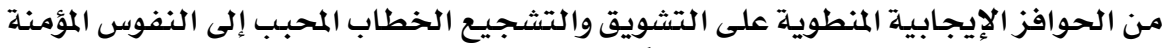

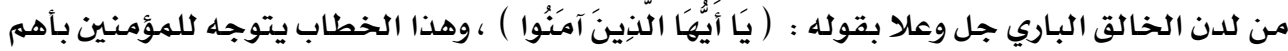

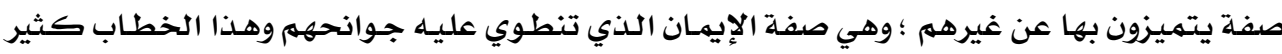

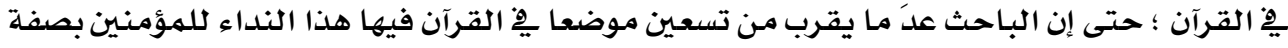

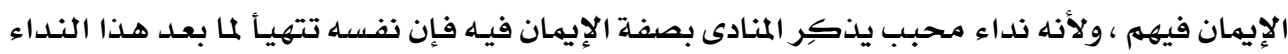

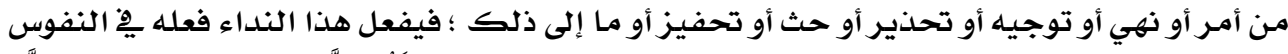

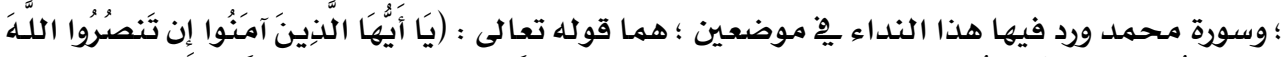

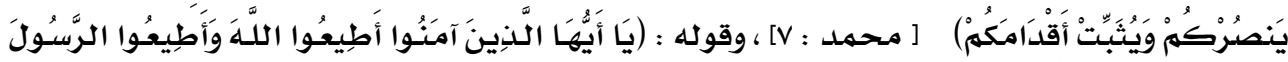

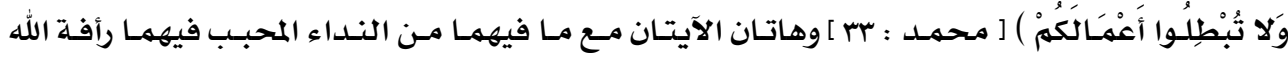

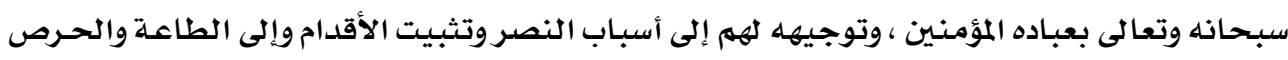

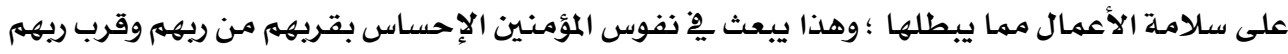

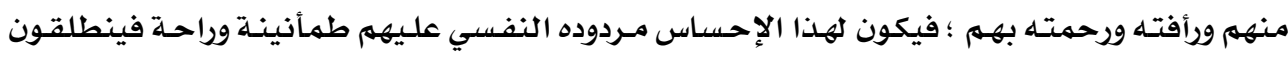

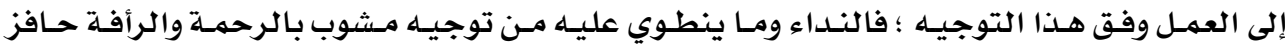

$$
\text { إيجابي للنفوس المؤمنـة . }
$$

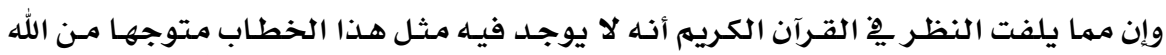

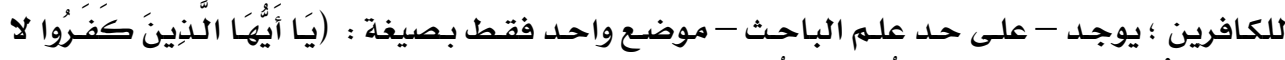

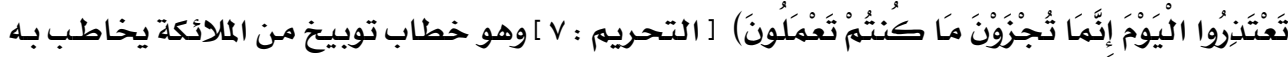


الكفار بعد دخولهم النار علىٍ سبيل التوبيخ واللوم وعدم قبول عذرهم ؛ فحـالهم أنهـم بعـداء عن الله لا

يستحقون منه خطابا مباشراً .

: م - اتباع الحق

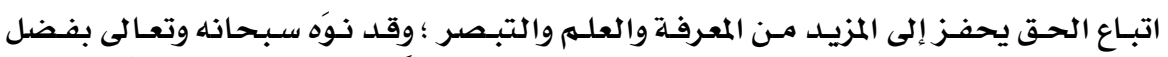

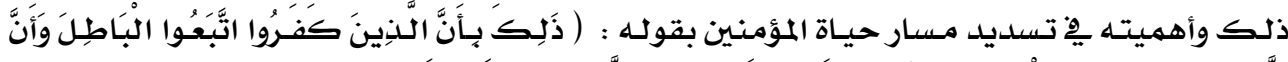

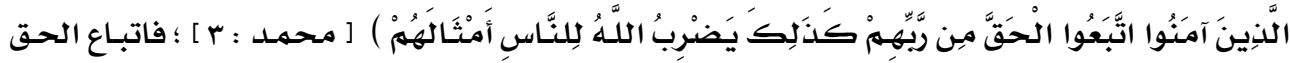

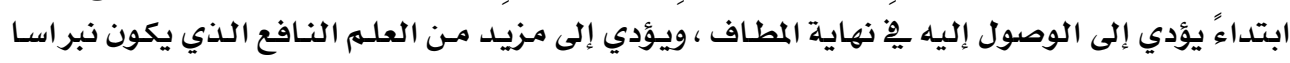

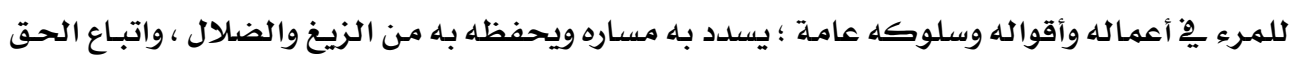

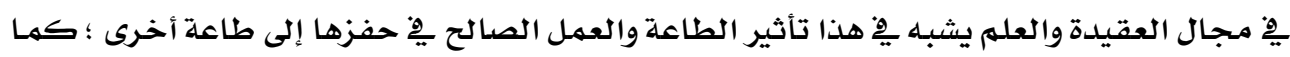

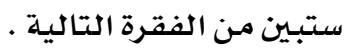

ع - العمل الصالح : 20

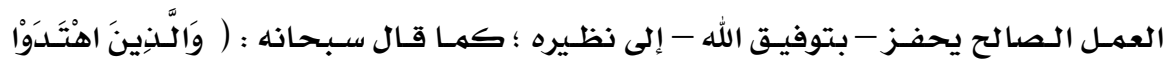

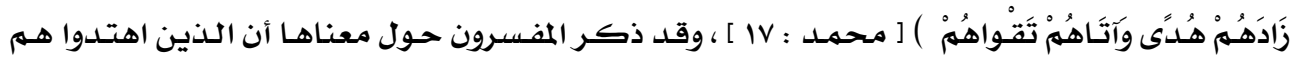

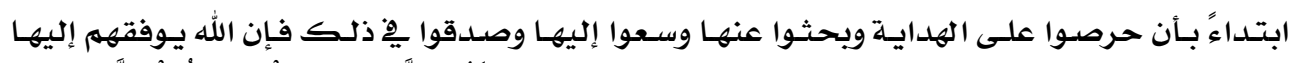

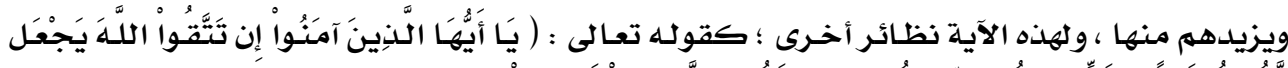

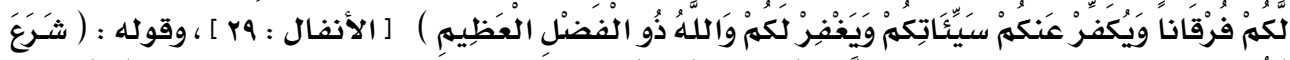

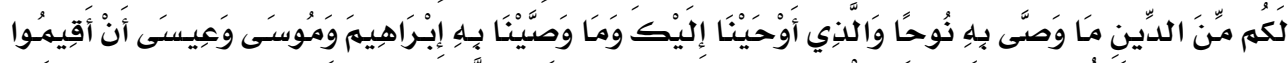

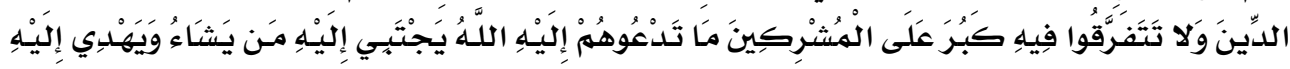

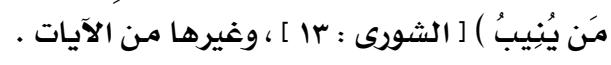

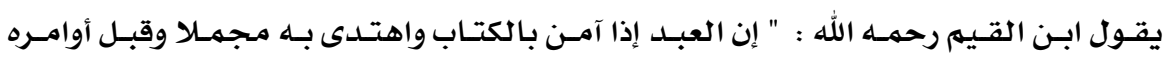

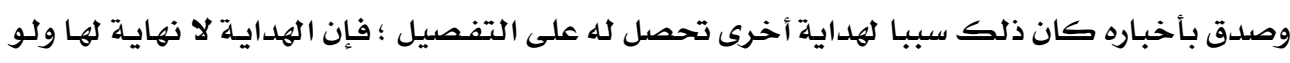

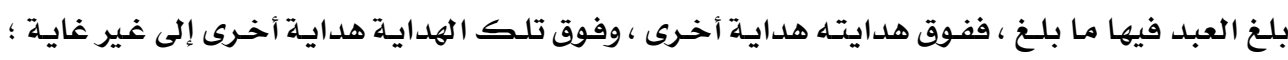

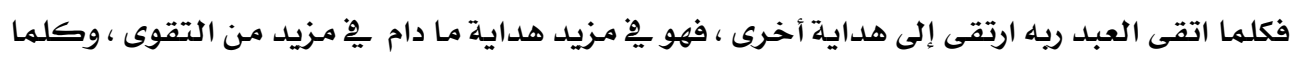

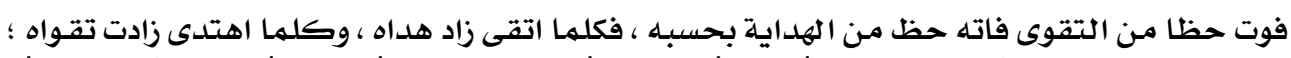

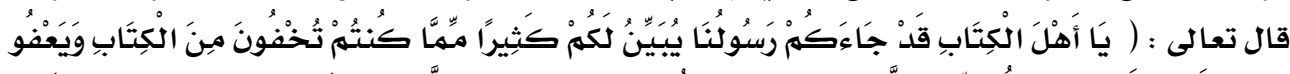

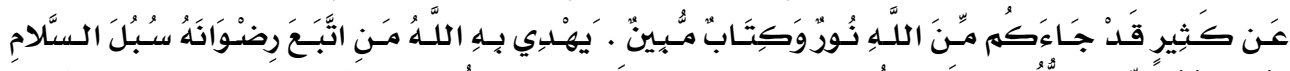

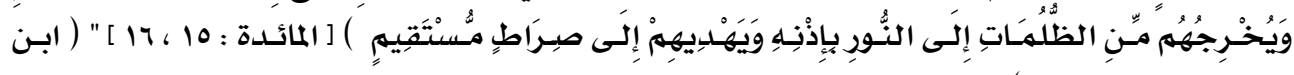

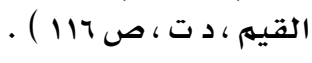

• - التقوى :

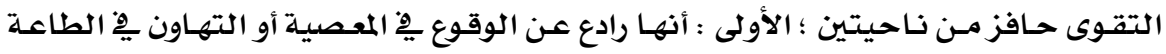

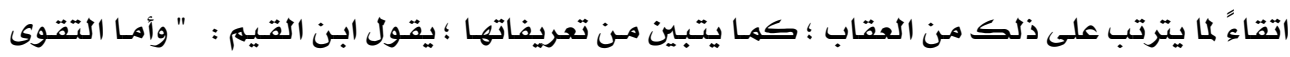

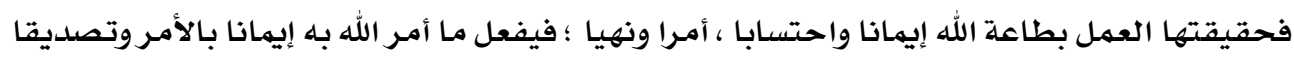




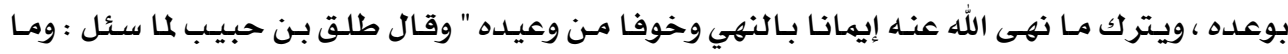

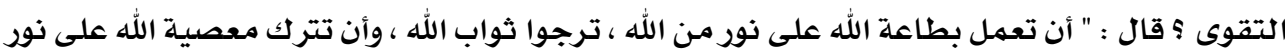

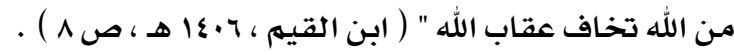

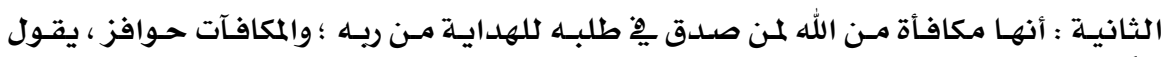

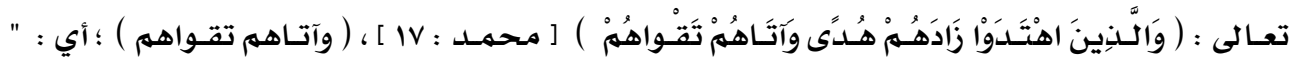

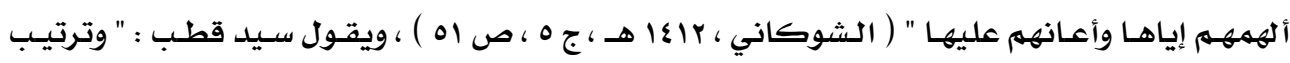

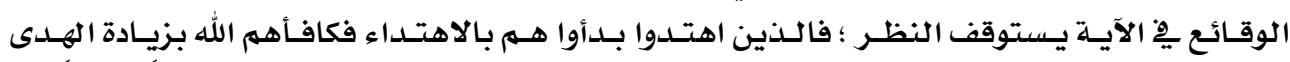

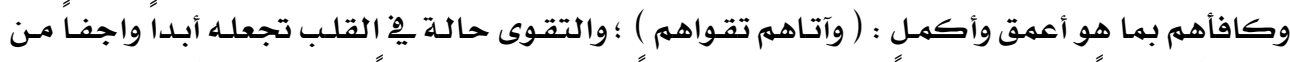

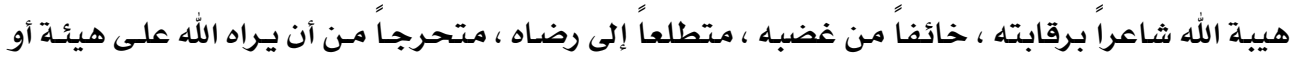

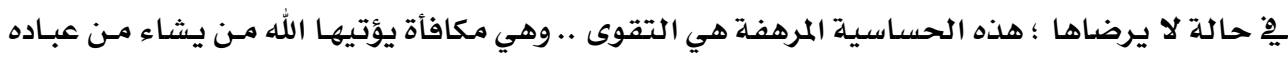

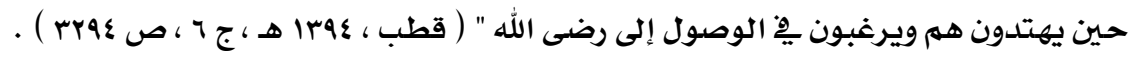

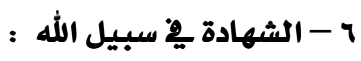

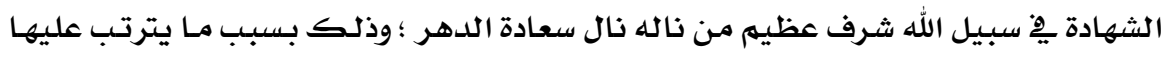

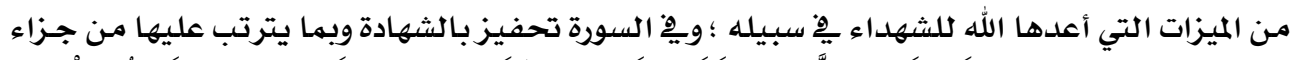

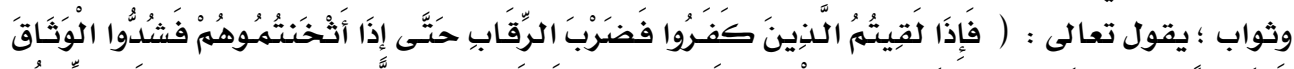

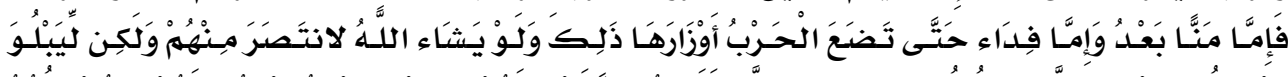

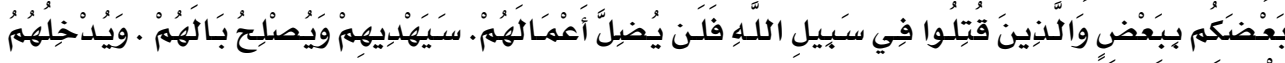

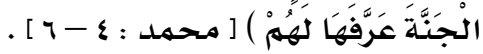

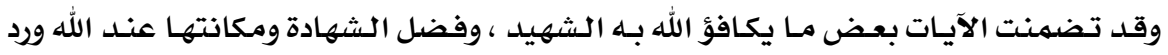

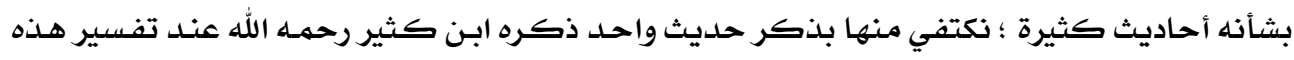

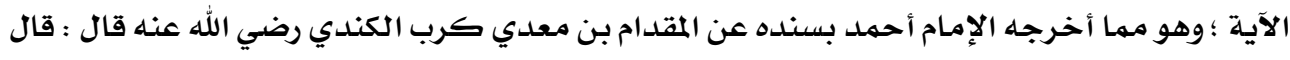

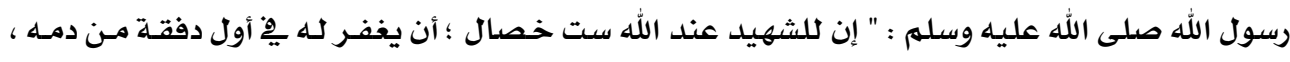

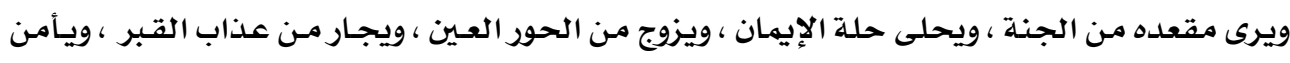

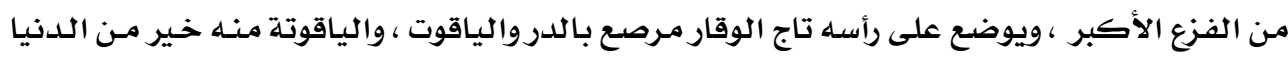

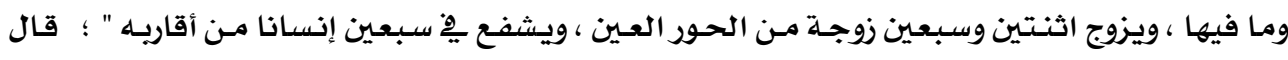

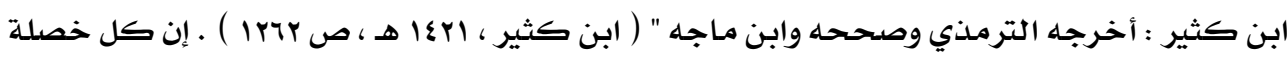

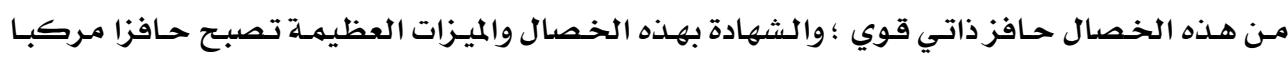

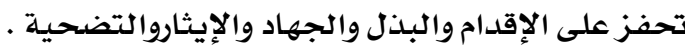

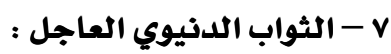

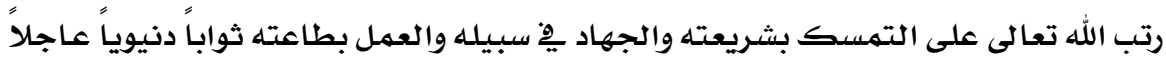

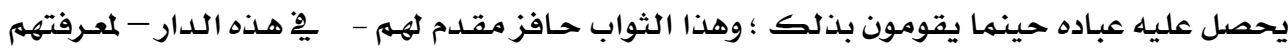

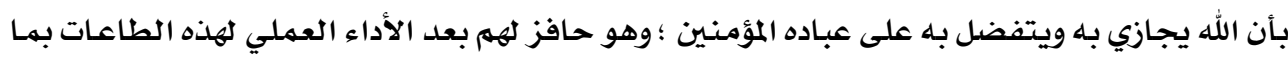


يجعله الله ِِِ النفوس مـن سـعادة وطمأنينـة وانتصـار وازديـاد مـن الهدى والرسـوخ واليقين بعـد أدائهـا ؛ وفيما يلي أهم ما تضمنته السورة من الثوس لثواب العاجل :

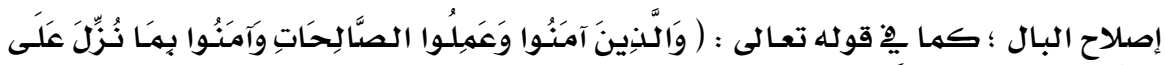

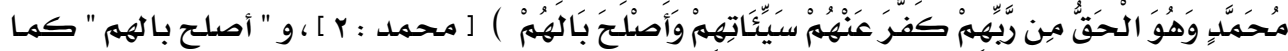

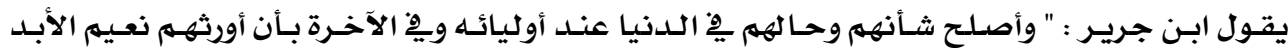

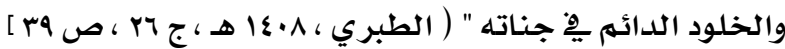
نصر الله للمؤمنـين وتثبيت أقدامهم إن هم نصروه ؛ فهو نصر مشروط ؛ ولذلك فيإن الوعد

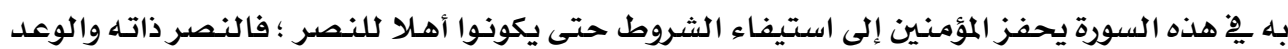

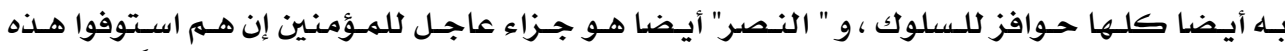

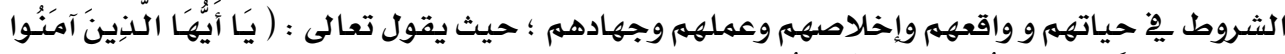

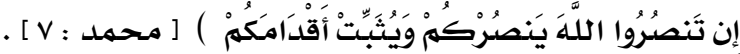
كما أنه تعالى ينصر من نصره فهو يزيـد المهتدين إليـه هـدى ويهـلأ قلوبهـم خشيلة وتقوى ، وهو من ثوابه العاجل ، وقد سبق بيان ذلك .

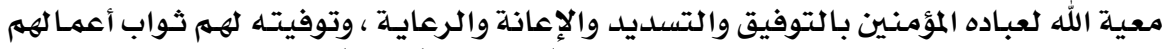

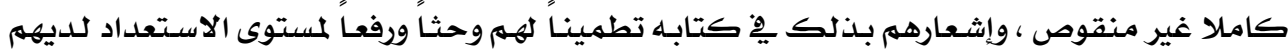

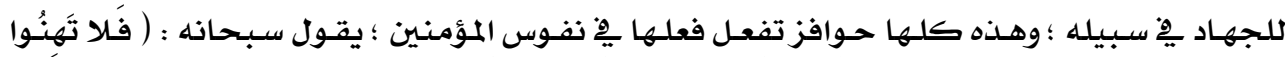

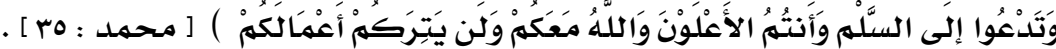

وٌِِ معرض تفسيره للآية بين الشيخ السعدي رحمـه الله مـا تشتمل عليه الآيـة مـن حوافز لها

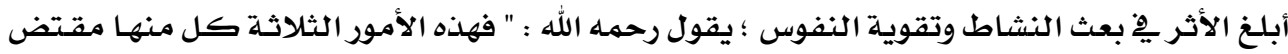

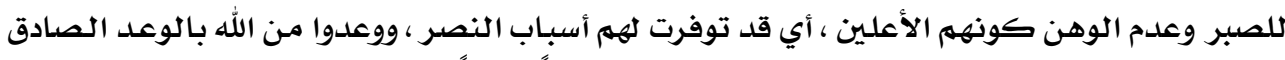

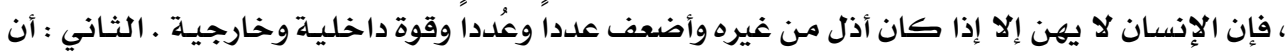

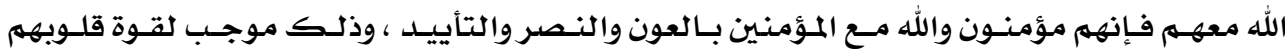

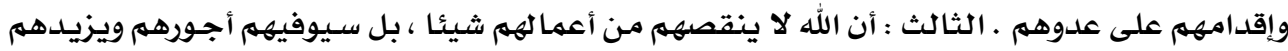

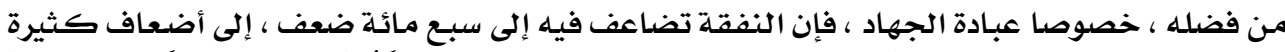

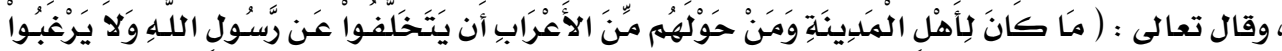

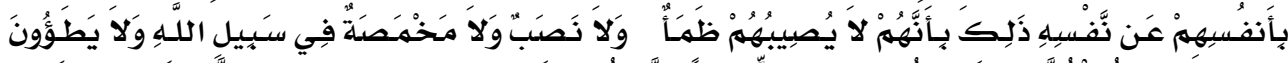

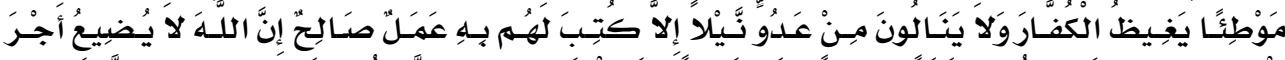

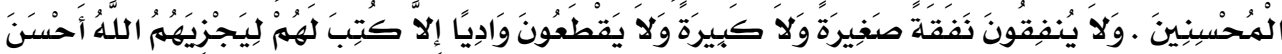

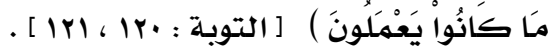

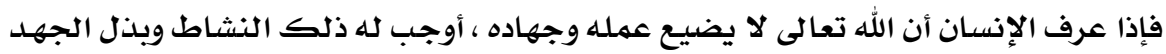

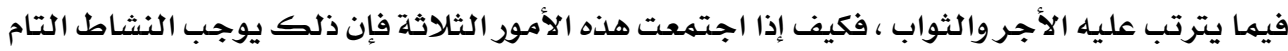


، فهذا من ترغيب الله لعباده وتنشيطهم وتقوية أنفسهم على مـا فيه صلاحهم وفلاحهم . ( السعدي ،

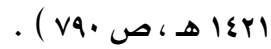

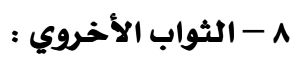

تحظى الحوافز الأخروية ِِّ الإسلام بالأهمية القصوى ؛ لأن الآخرة هي دار القراروالخلود ،

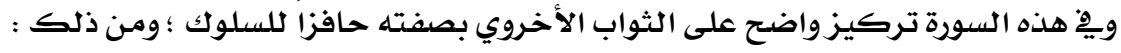

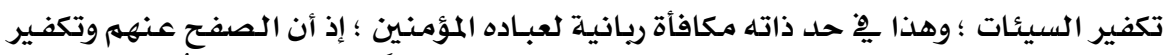

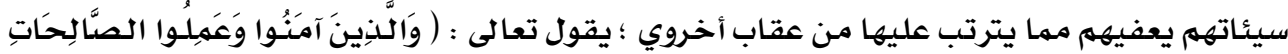

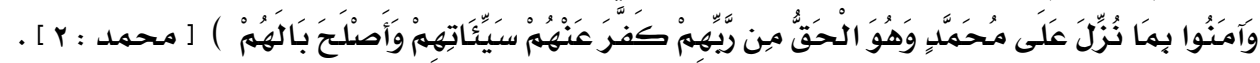

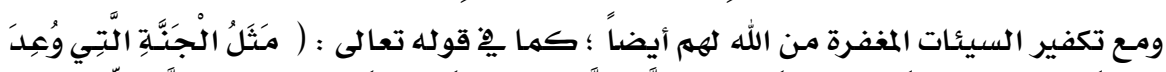

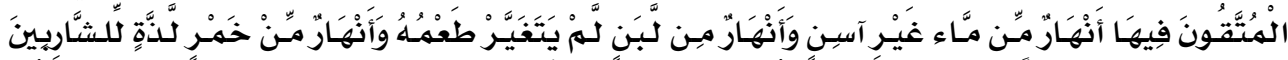

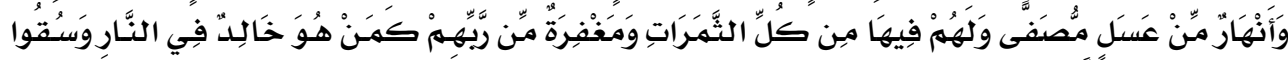

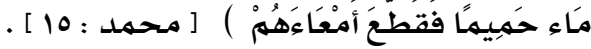

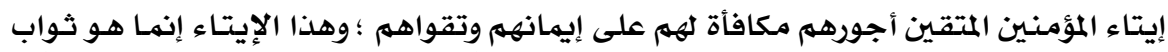

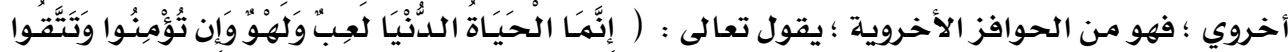

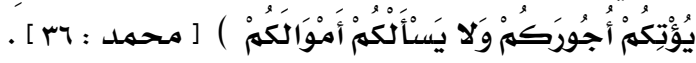

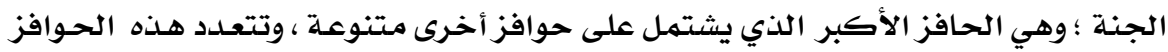

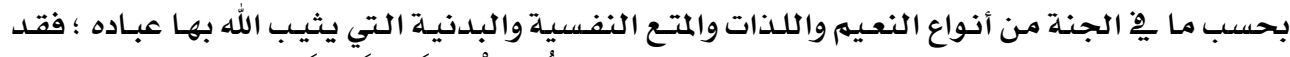

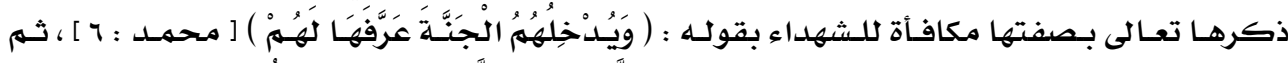

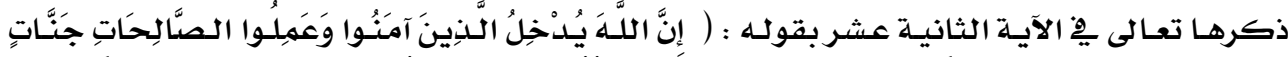

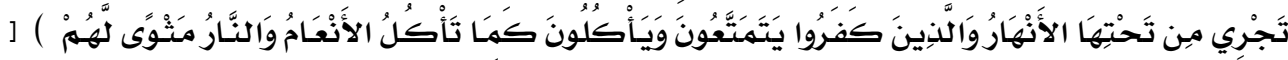

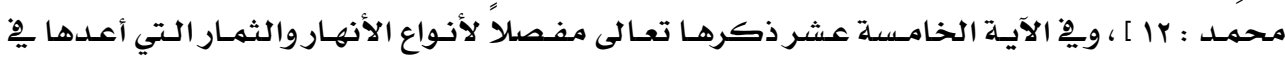

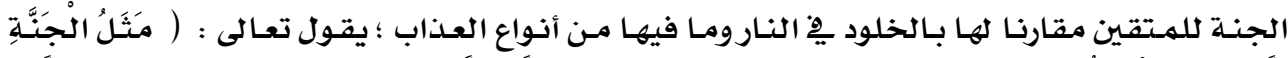

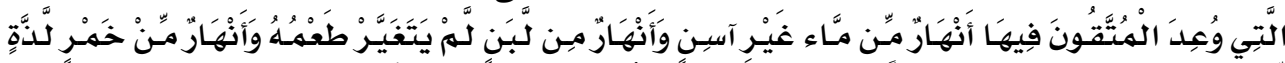

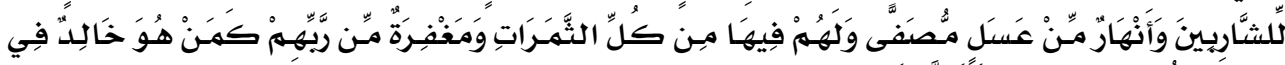

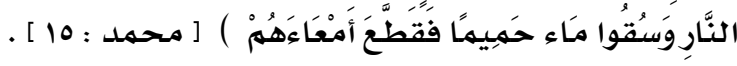

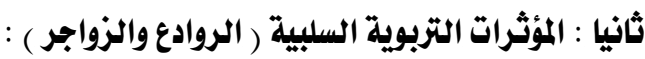

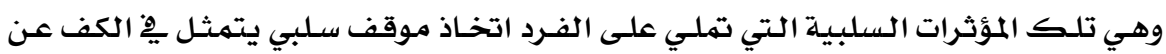

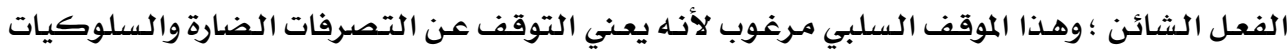

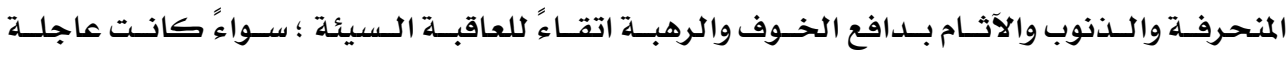

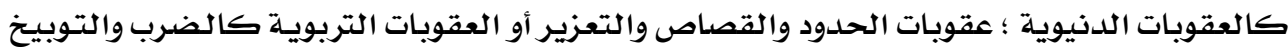

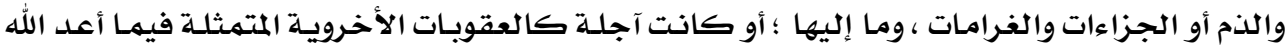


للعصاة من عقوبات متنوعة ؛ فهي روادع وزواجر تردع عن المضي يف السلوك السيء وتزجـر عنسه ؛وفيما

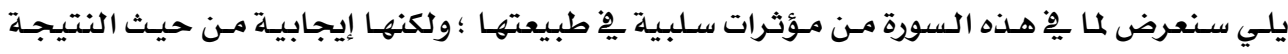
المرغوبة التي تؤدي إليها ؛وهي : لئسي 1- - ملم الله المحيط بعباده :

إن أسماء الله وصفاته عموماً تؤثر يِ المؤمنـين بها ؛ فصفة الرحمـة والرأفة مـثلا تقوي رجـاء

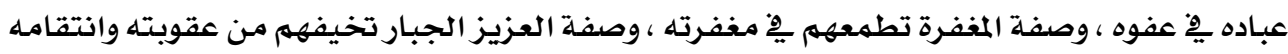

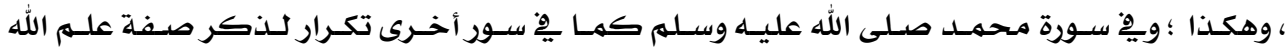

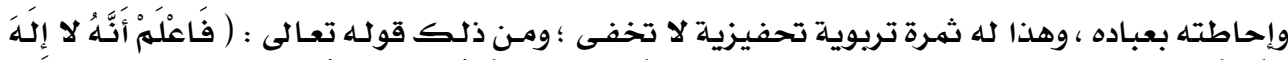

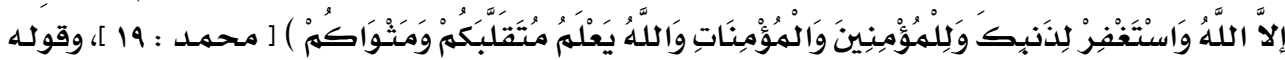

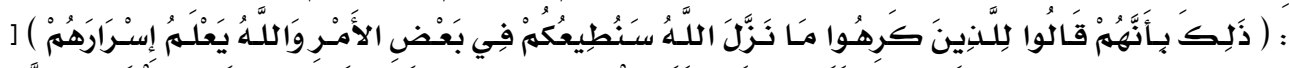

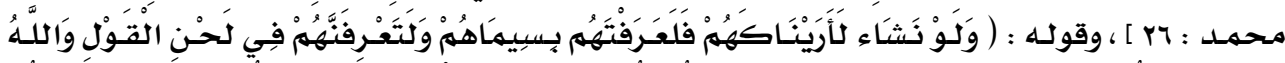

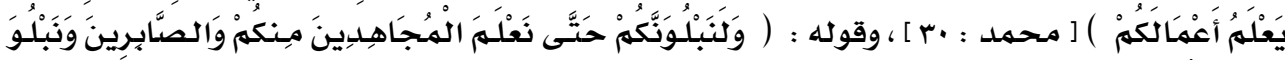

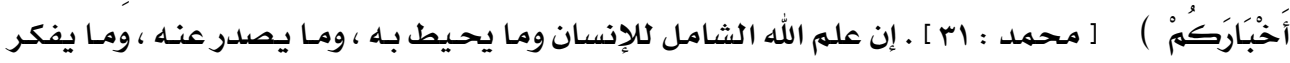

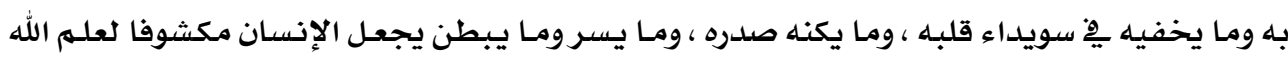

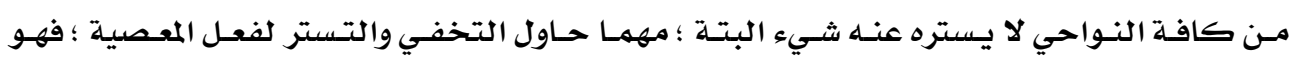

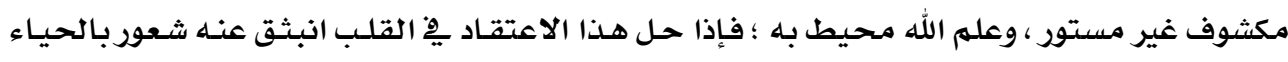

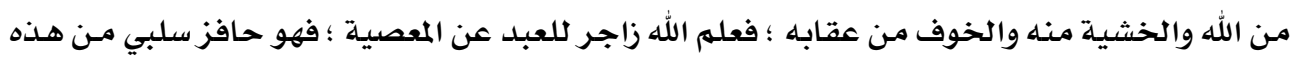

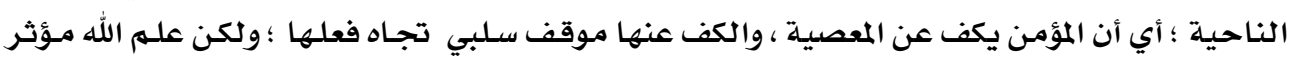

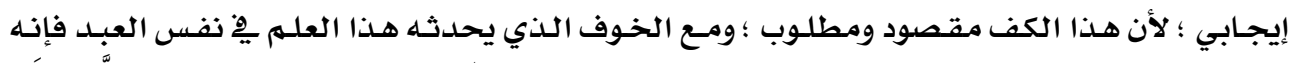

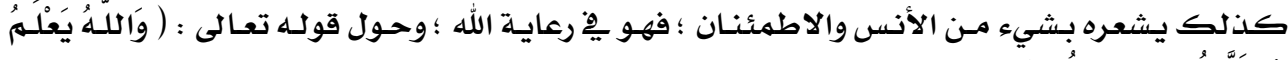

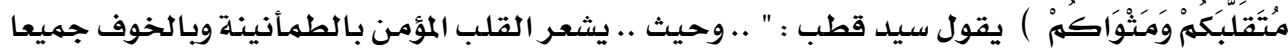

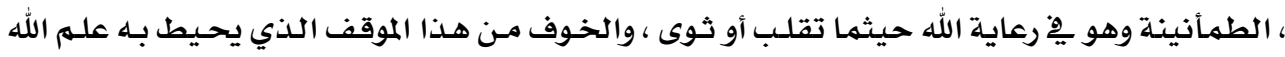

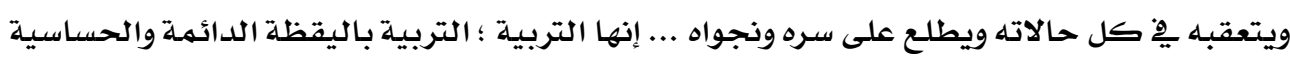

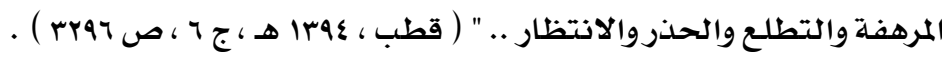
: r r التوبيخ والإنكار

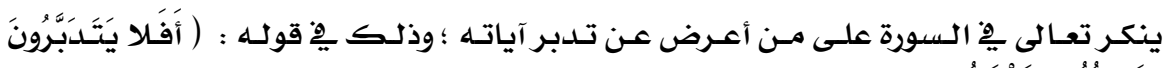

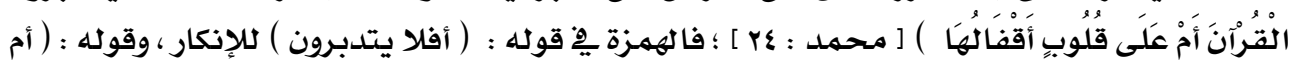

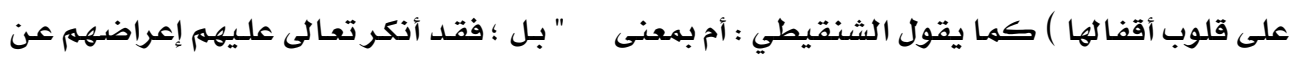

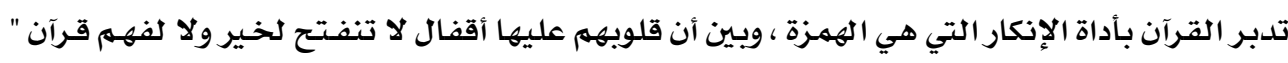

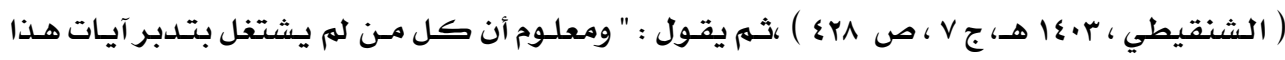

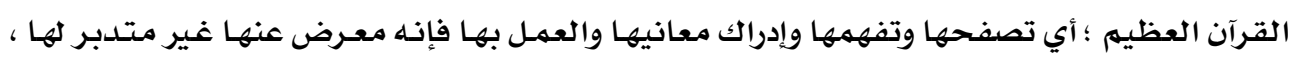

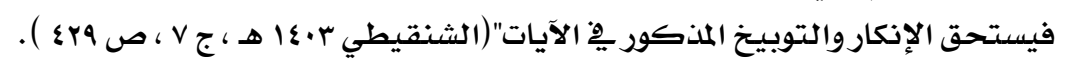




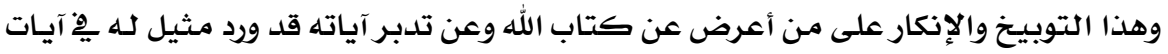

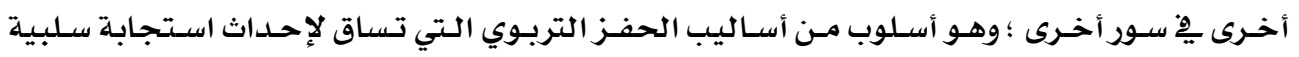

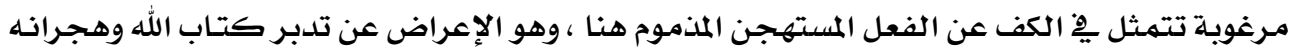

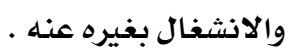

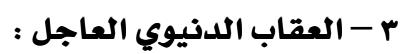

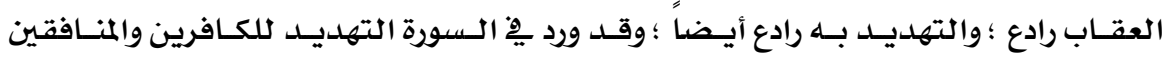

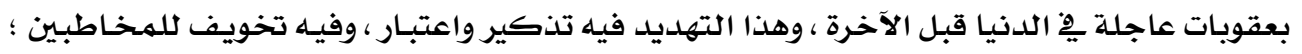

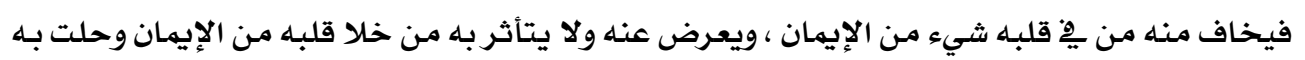

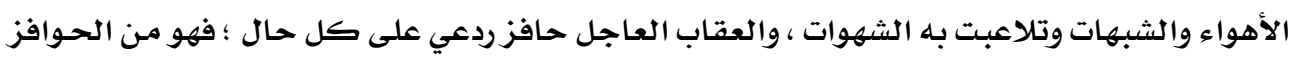

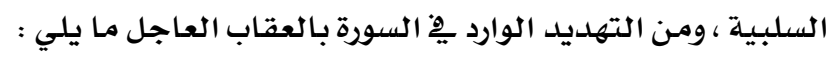

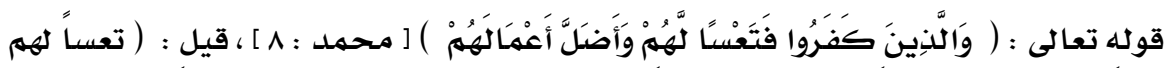

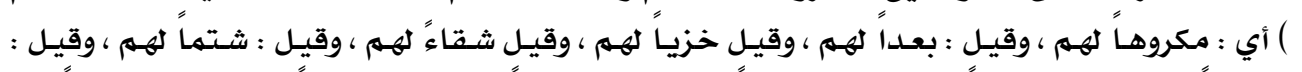

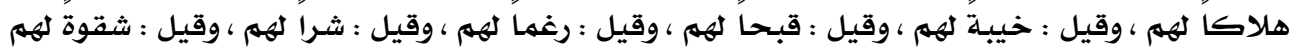

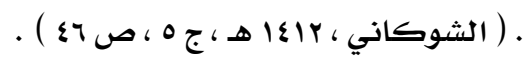

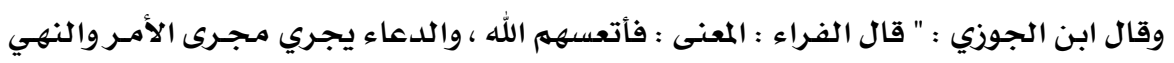

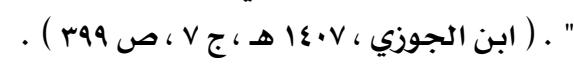

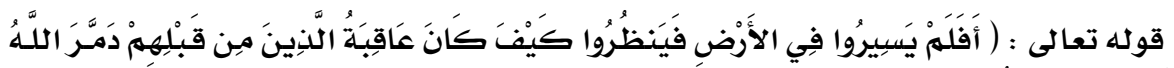

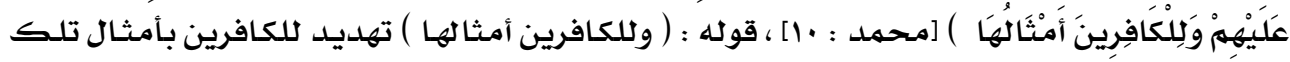

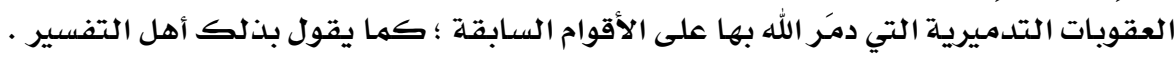

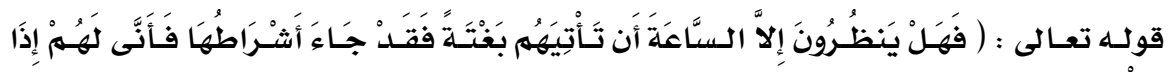

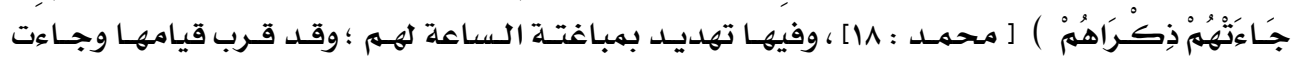
علاماتها .

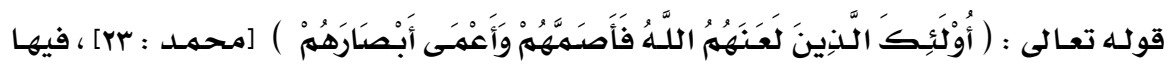

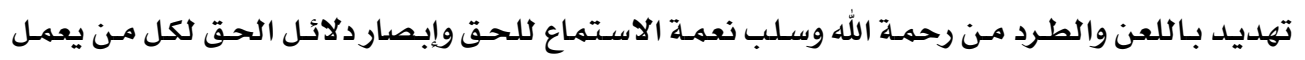

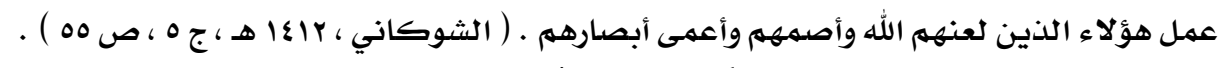

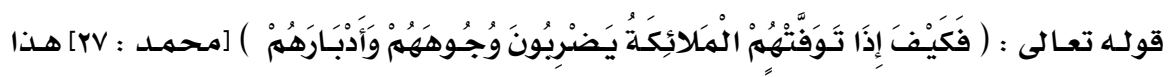

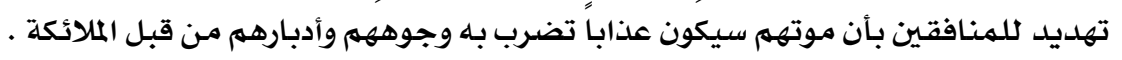

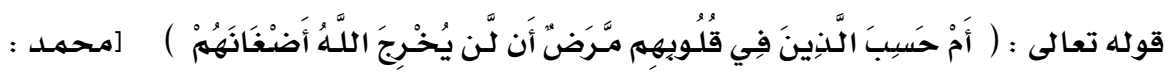

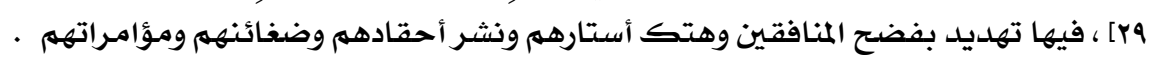

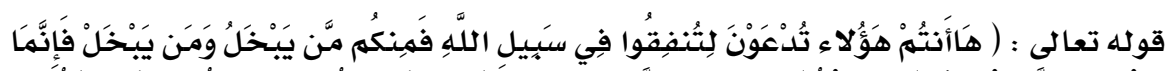

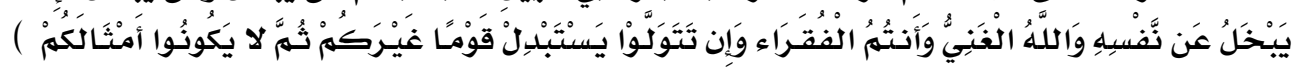




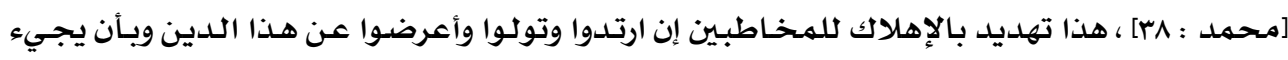

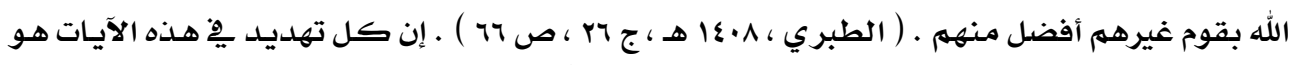

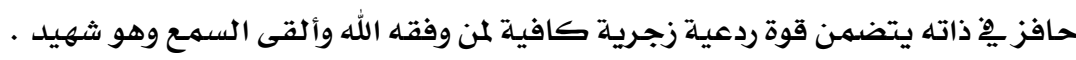

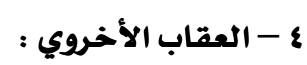

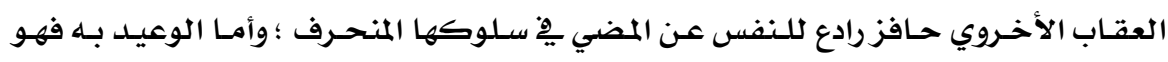

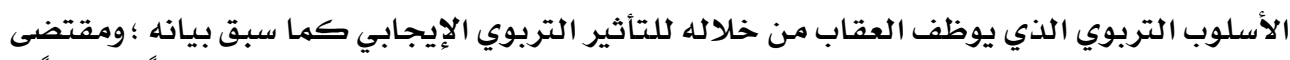

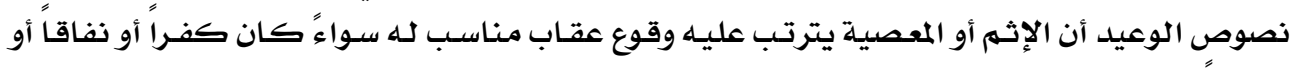

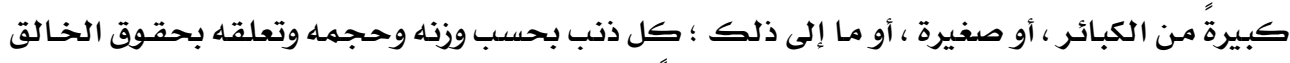

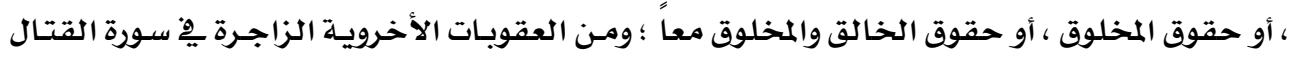

$$
\text { ما يأتي : }
$$

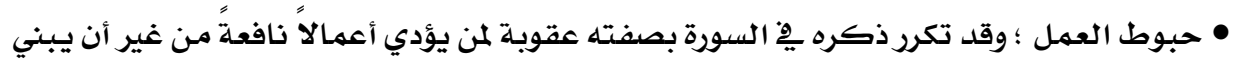

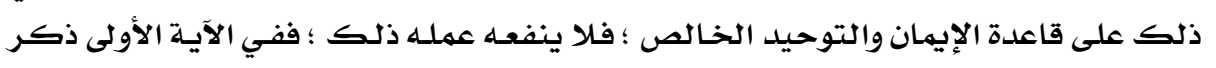

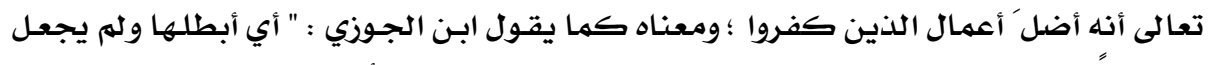

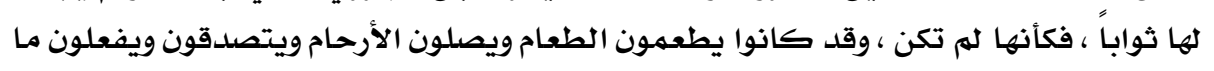

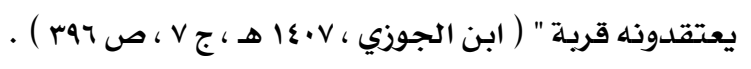

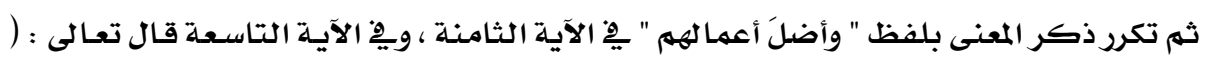

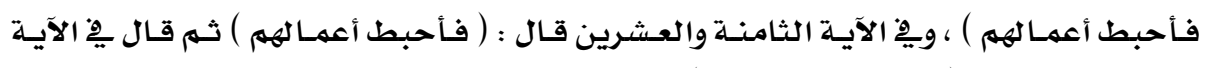

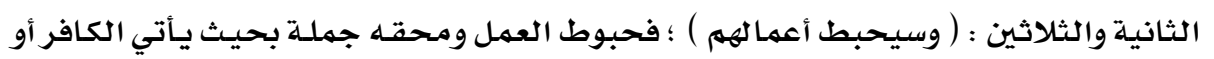

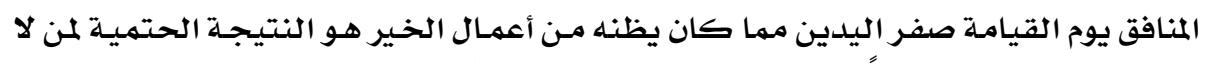

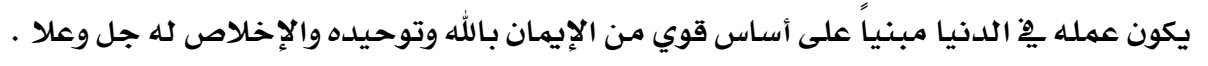

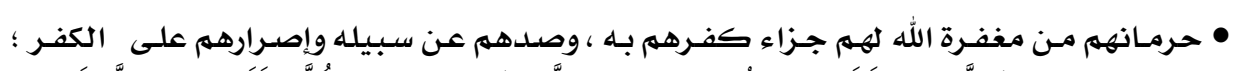

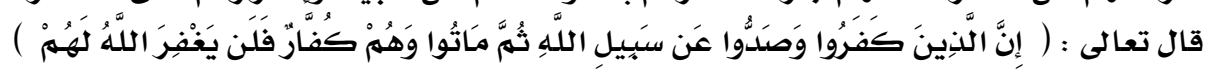

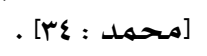

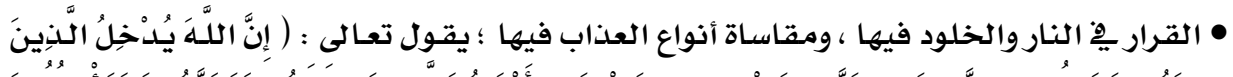

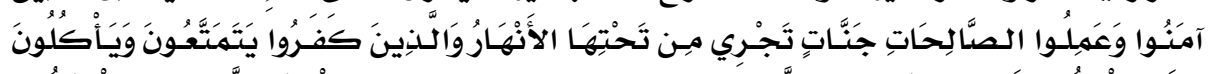

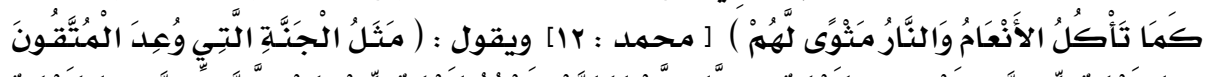

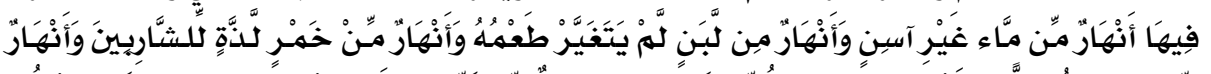

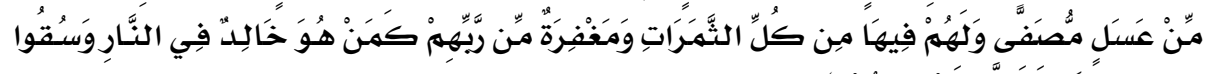

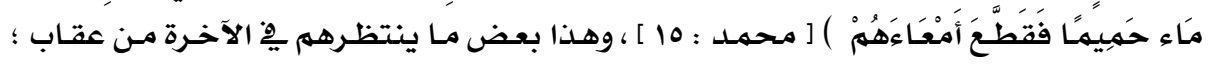

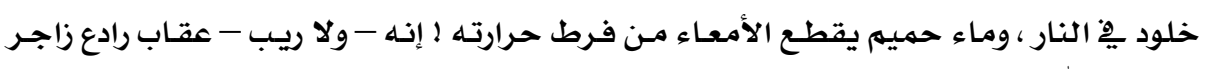

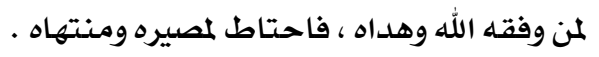




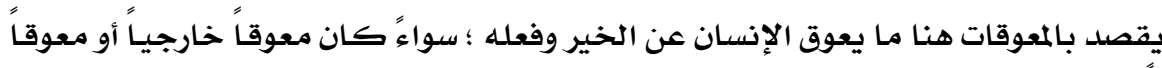

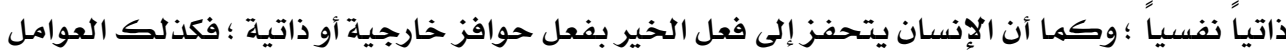

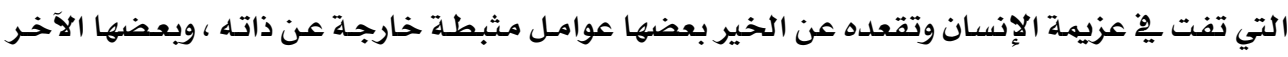

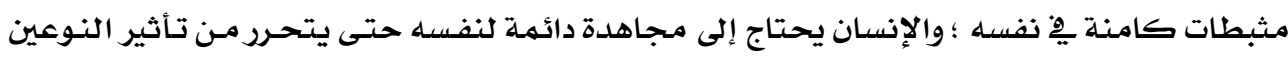

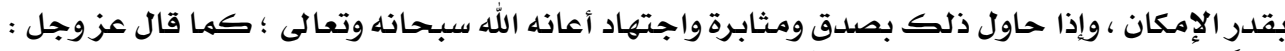

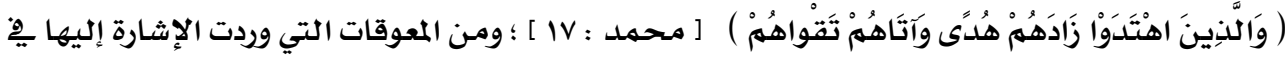

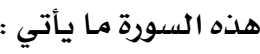

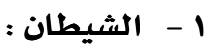

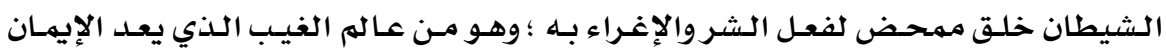

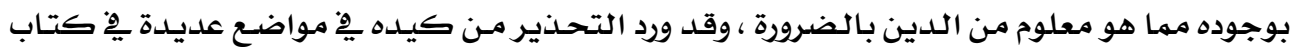

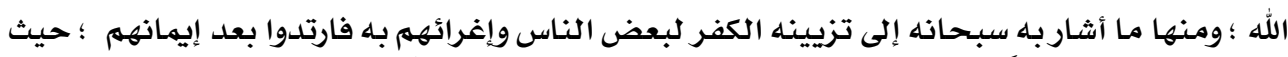

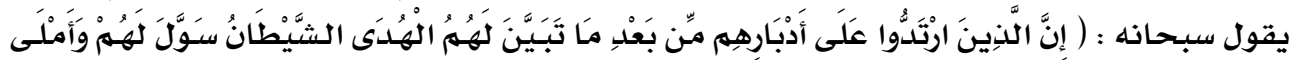

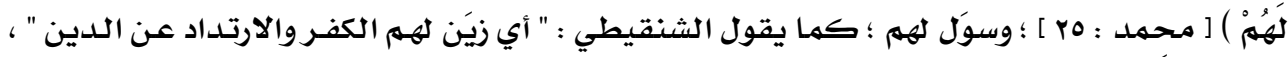

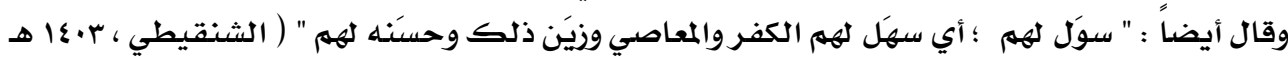

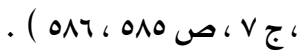

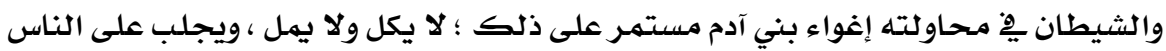

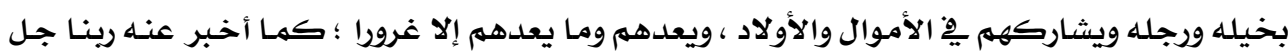

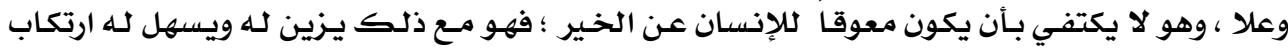

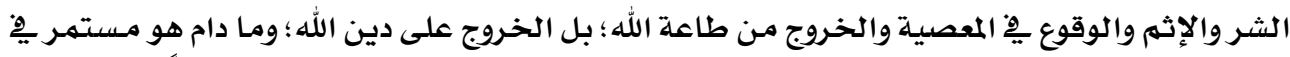

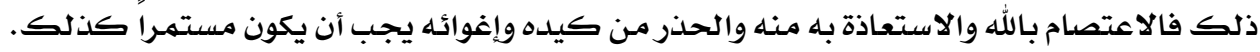

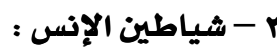

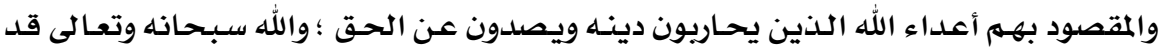

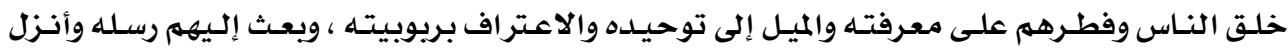

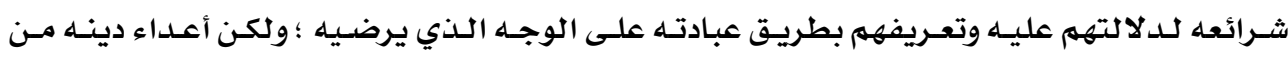

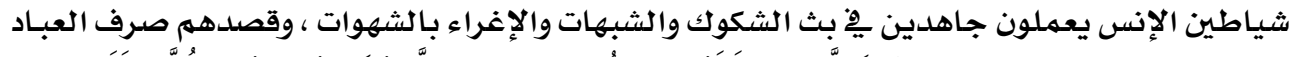

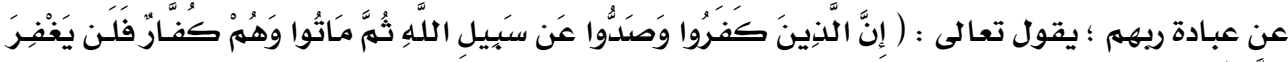

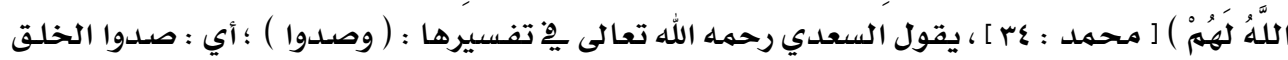

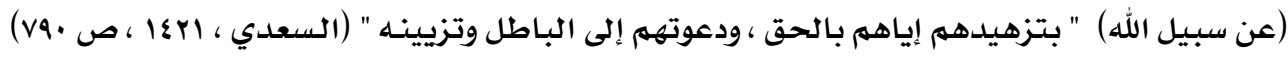

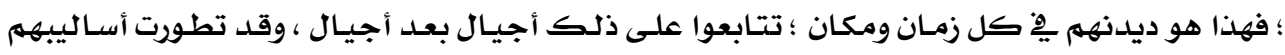

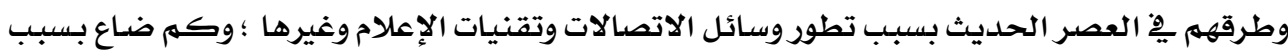




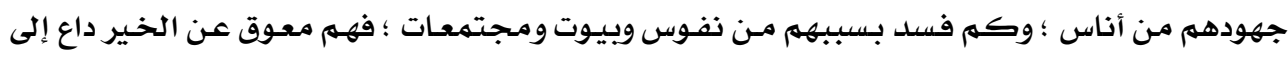

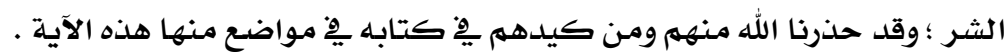

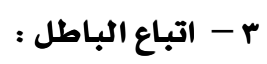

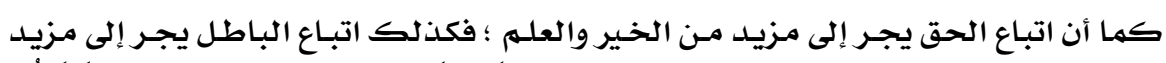

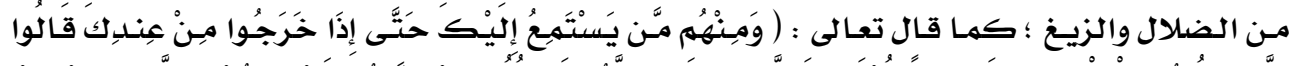

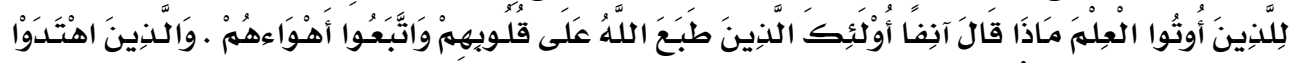

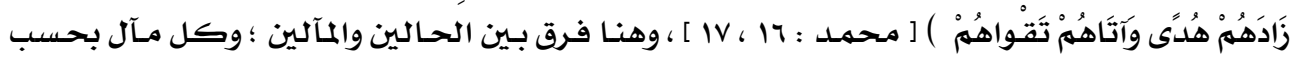

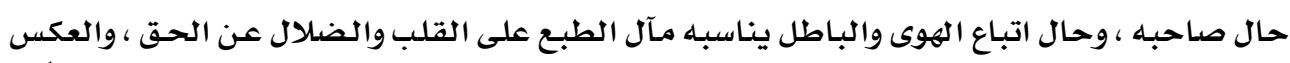

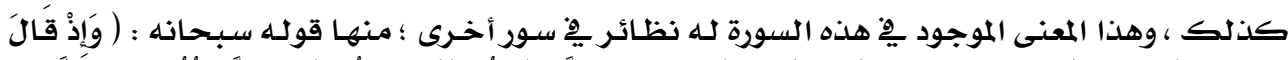

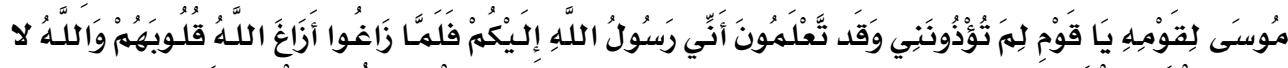

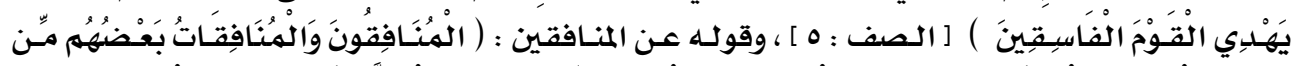

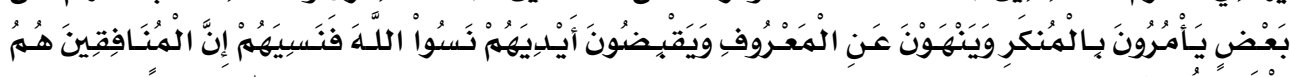

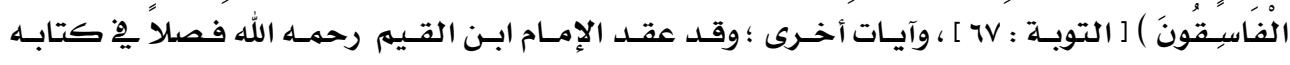

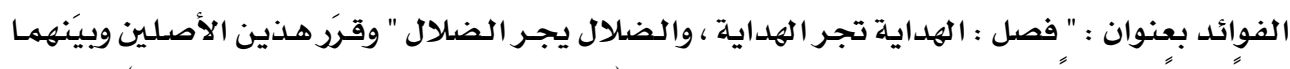

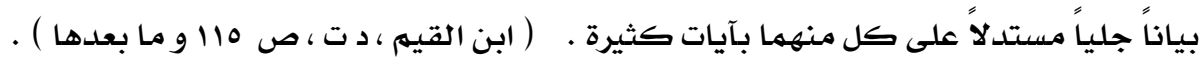

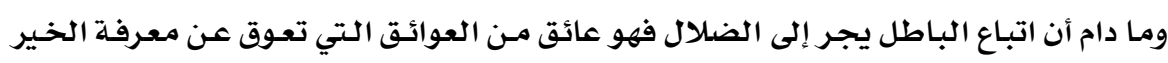

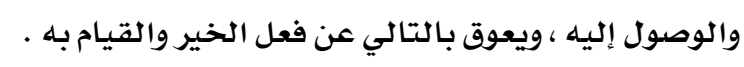

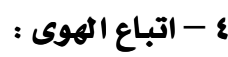

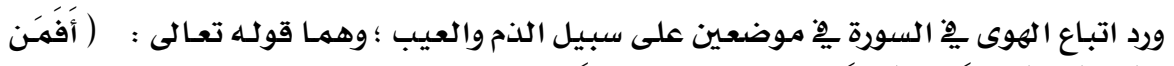

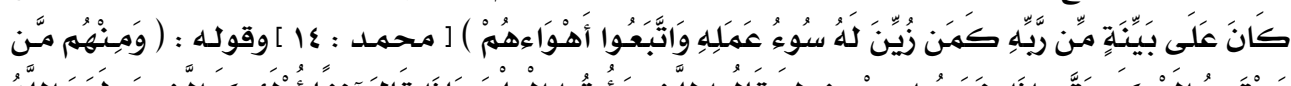

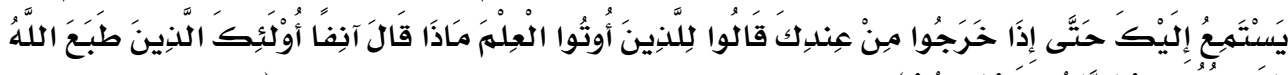

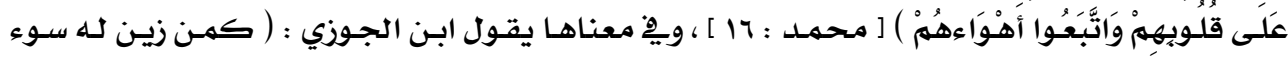

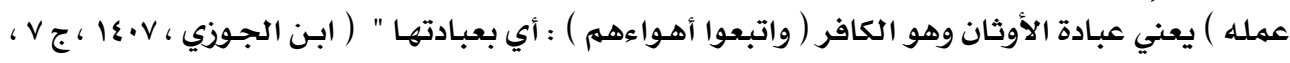

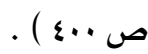

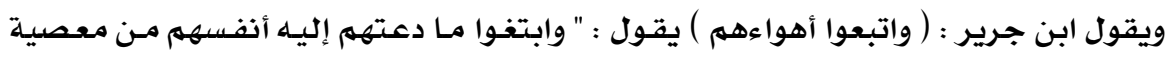

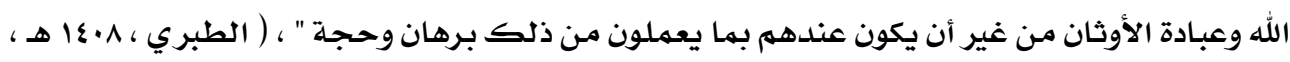

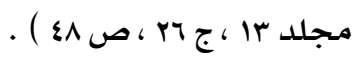

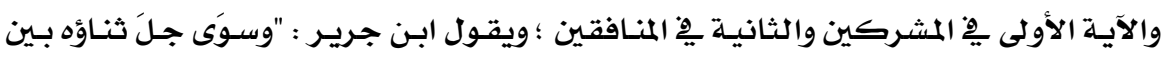

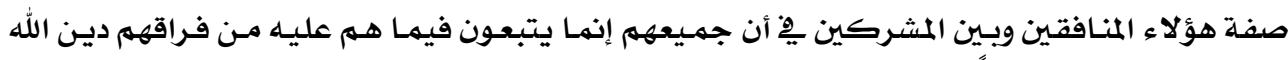

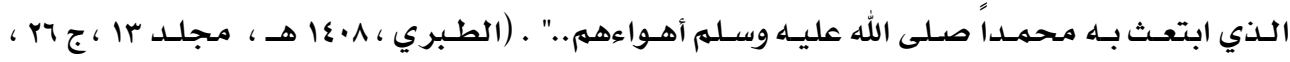

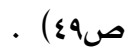




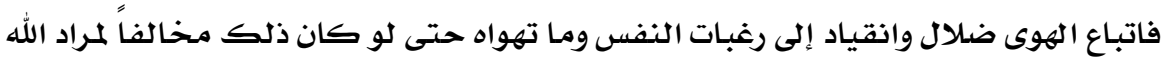

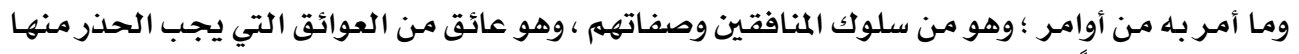

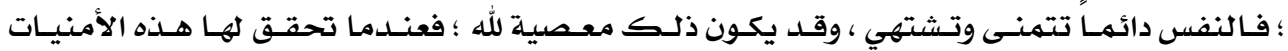

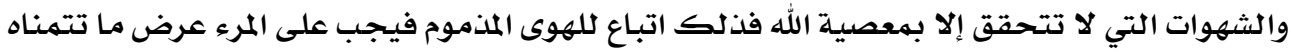

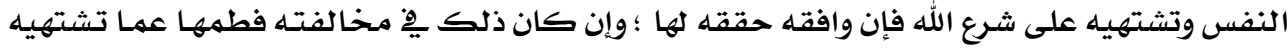

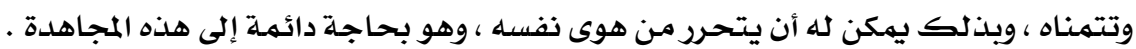

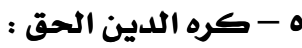

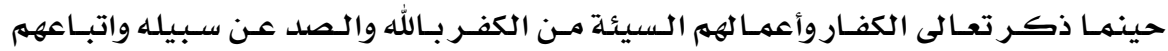

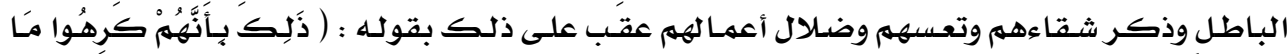

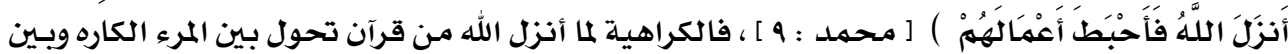

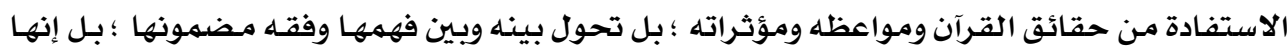

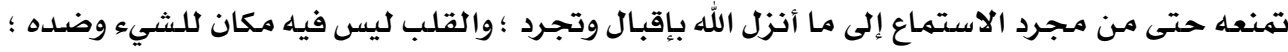

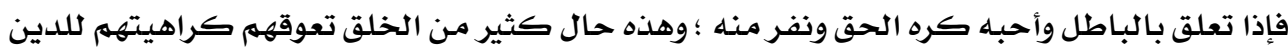

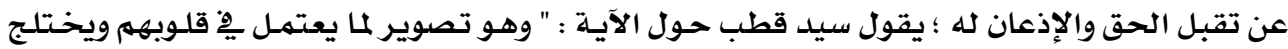

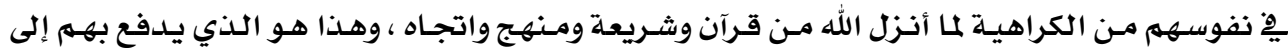

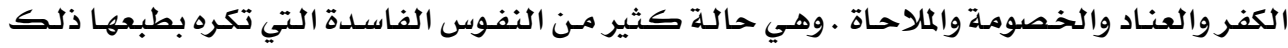

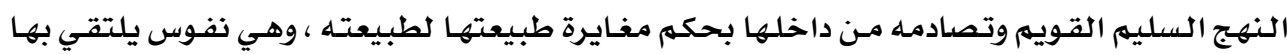

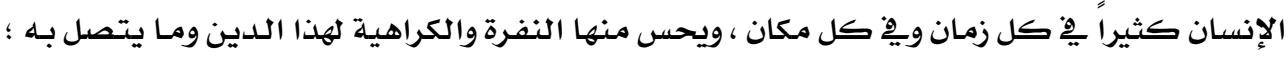

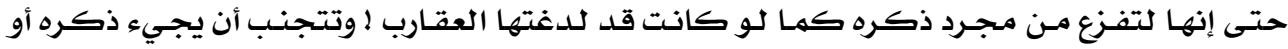

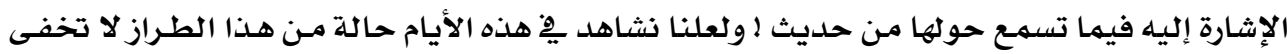

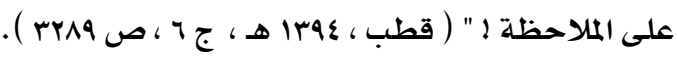

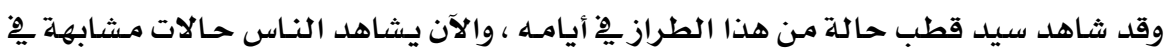
أيامنا هذه ؛ والله المستعان . اهل

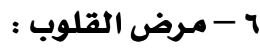

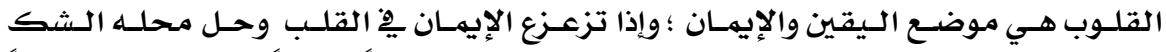

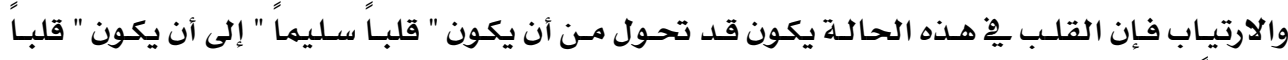

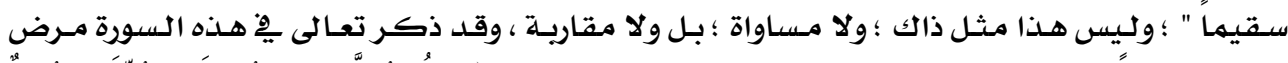

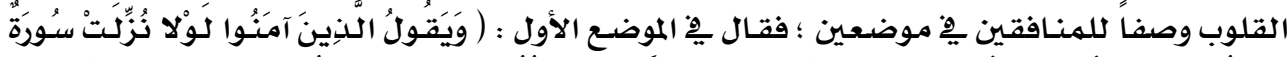

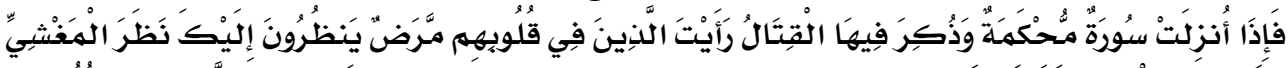

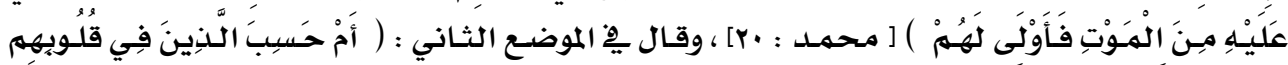

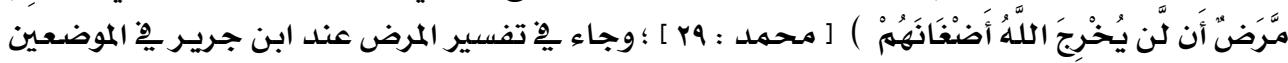

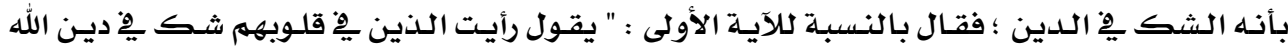




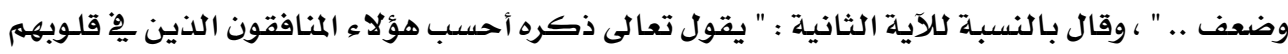

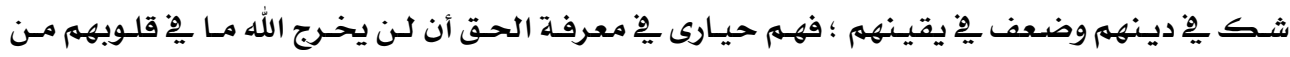

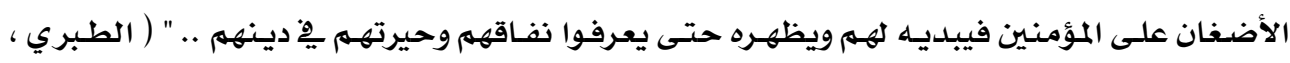

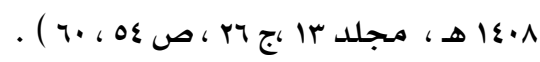

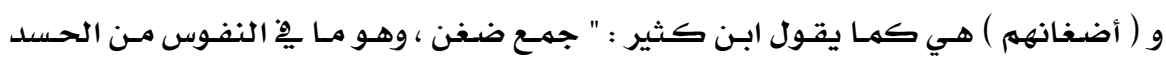

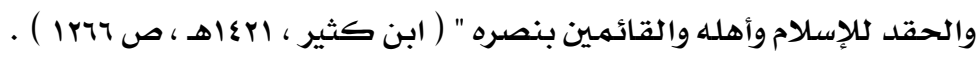

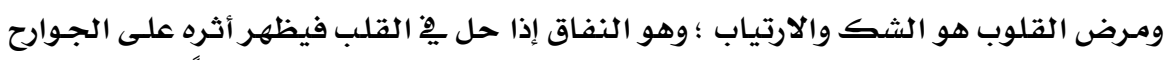

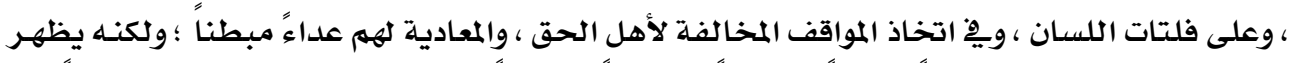

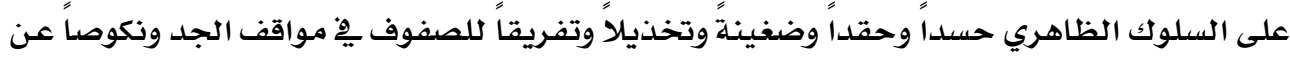

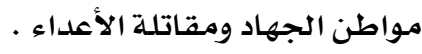

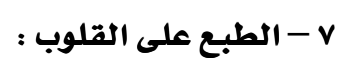

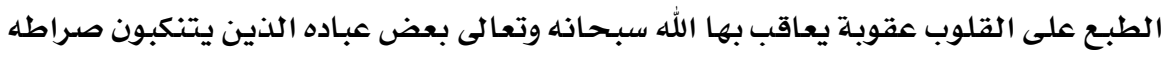

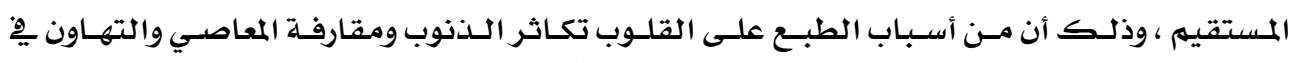

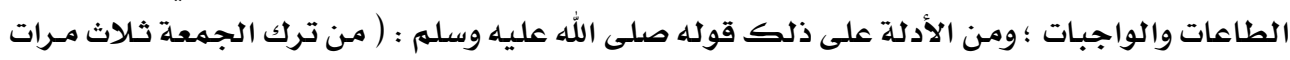

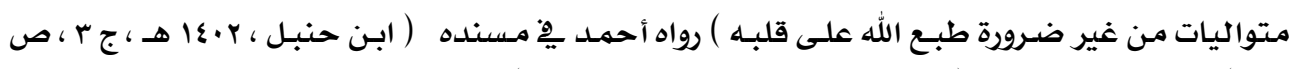

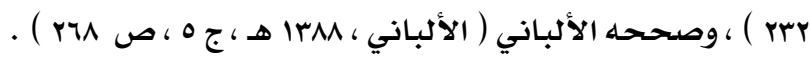

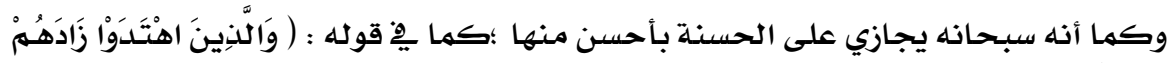

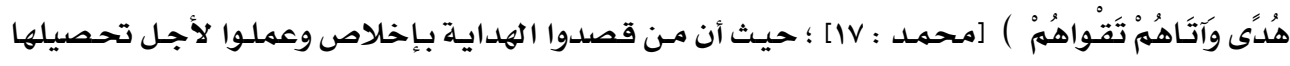

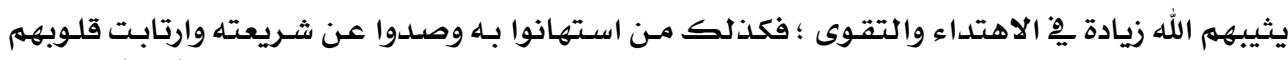

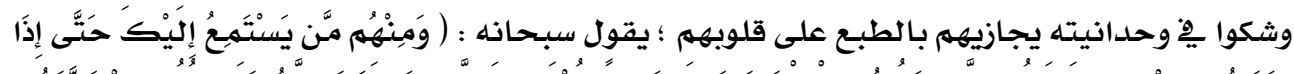

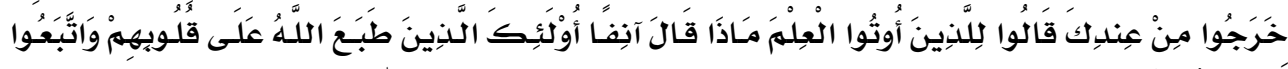

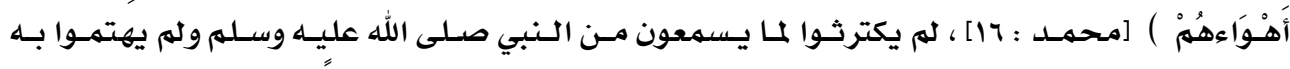

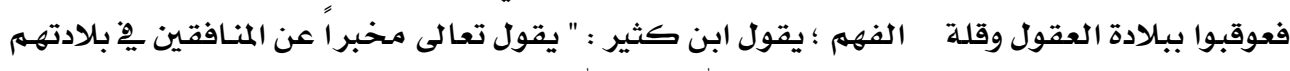

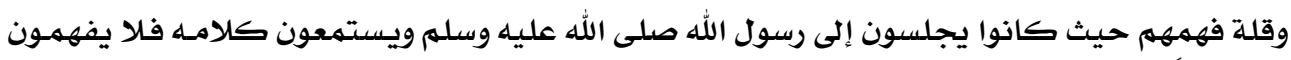

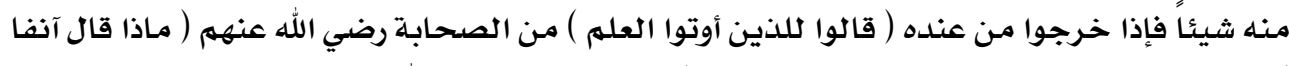

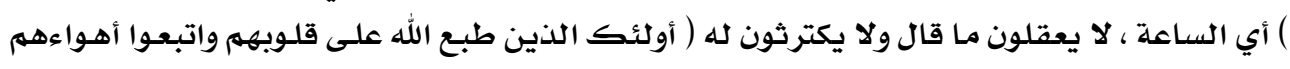

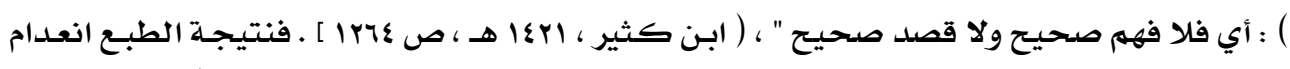

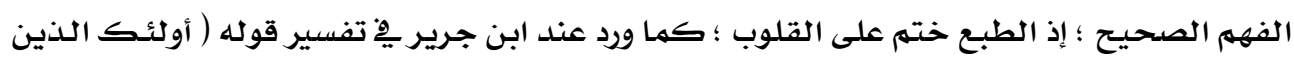

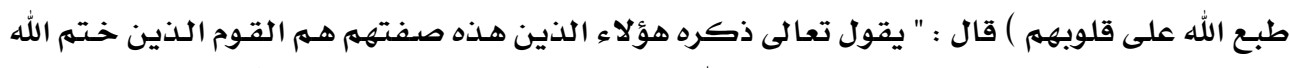

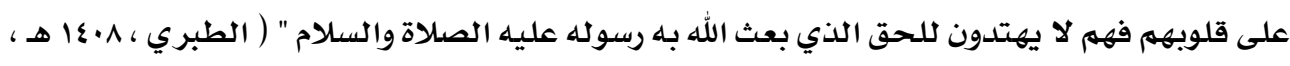

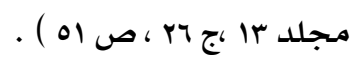


1 - الإقفال على القلوب ( انقفال القلوب ) :

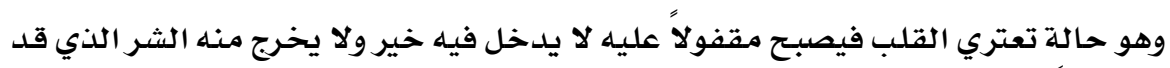

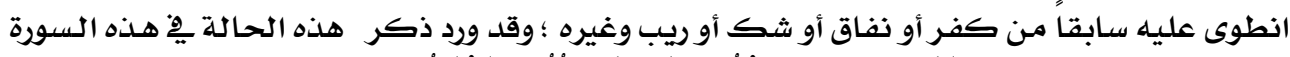

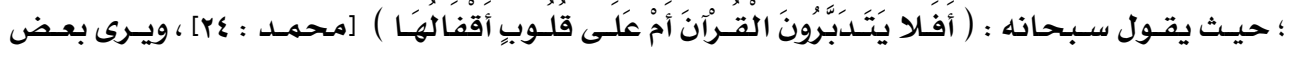

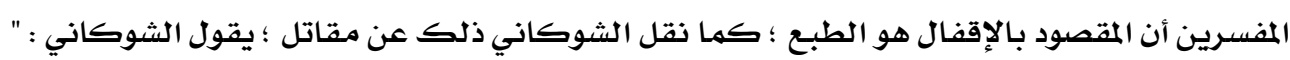

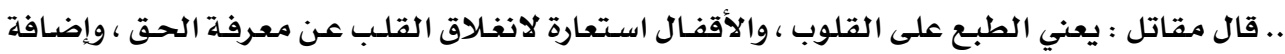

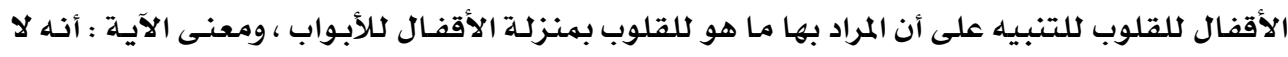

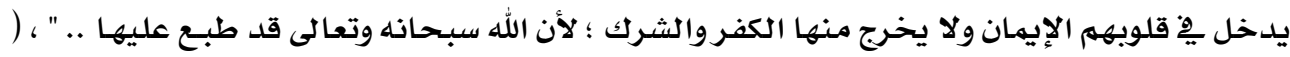

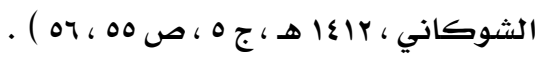

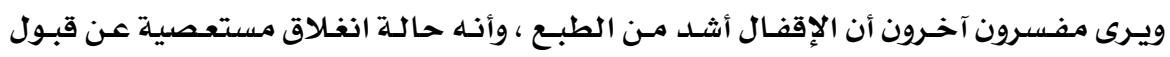

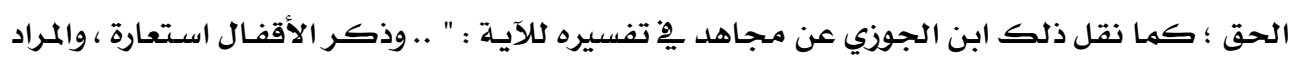

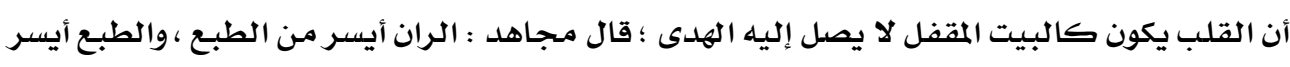

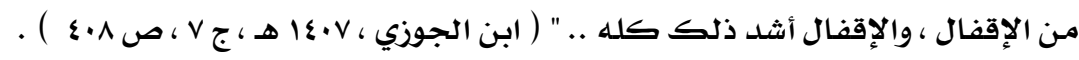

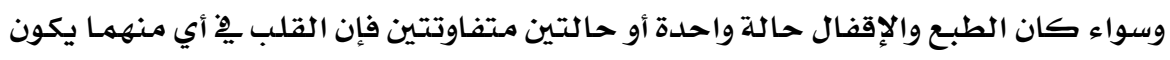

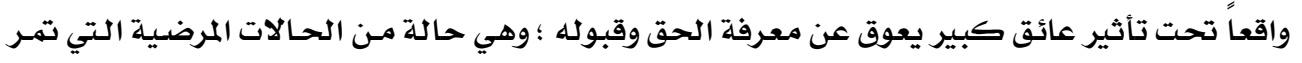

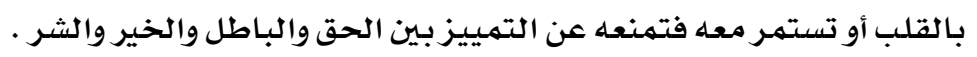

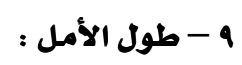

طول الأمل من المعوقات ؛ لأنه يكون مدعاة للتسويف ، والتسويف مضيعة للأوقات والطاقات

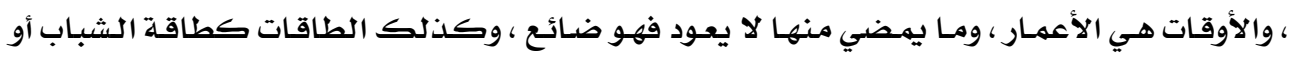

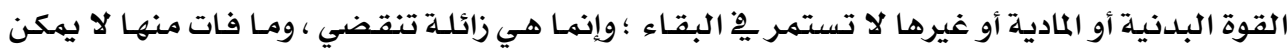

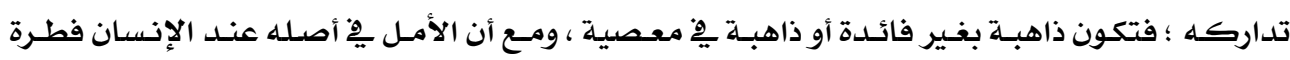

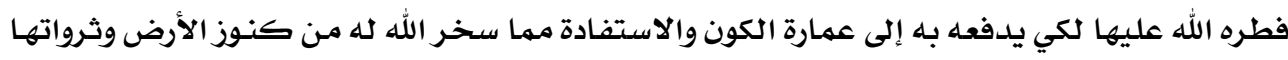

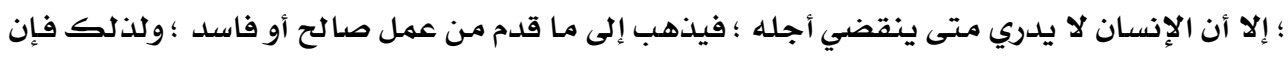

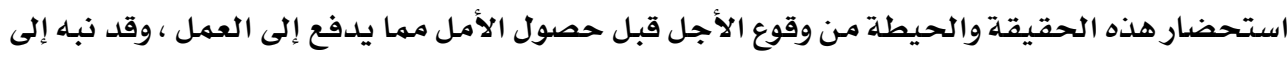

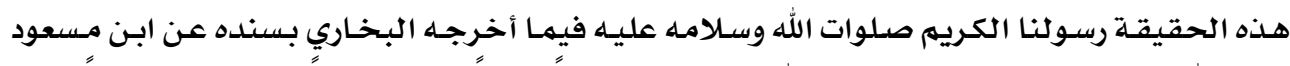

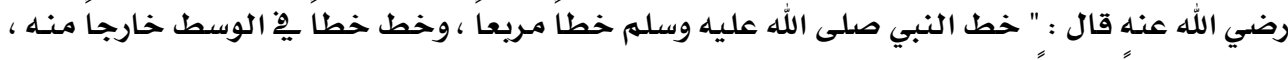

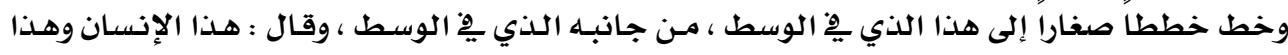

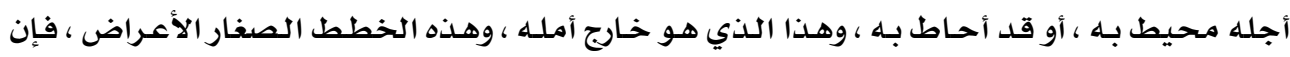

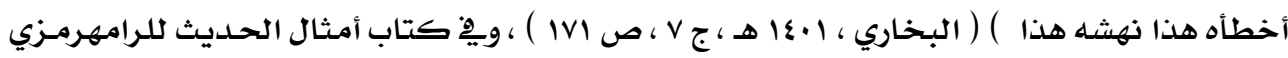

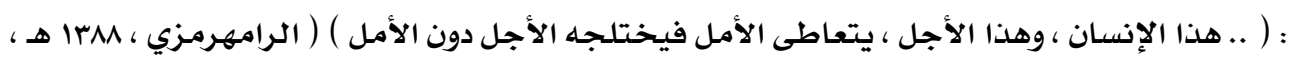




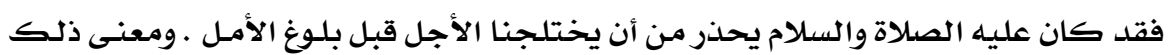

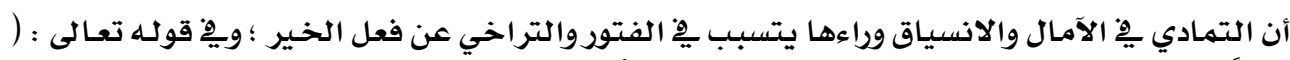

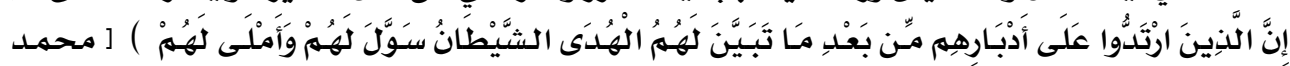

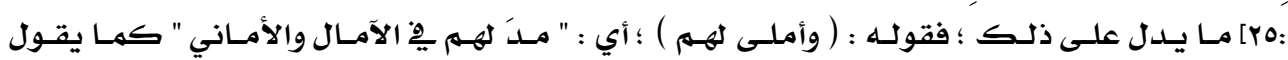

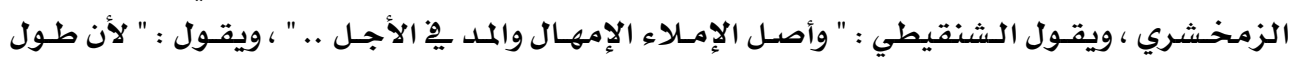

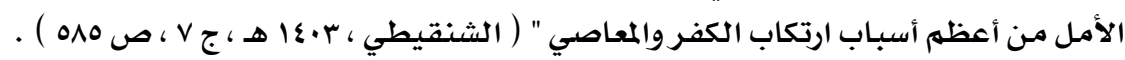

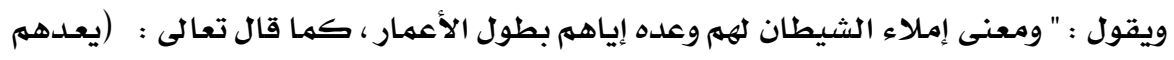

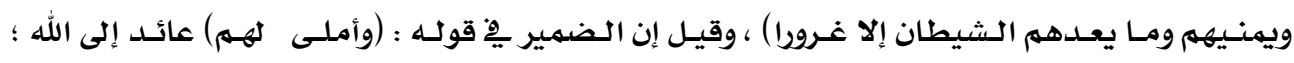

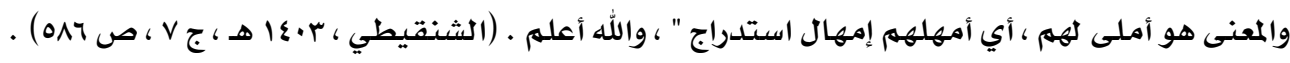

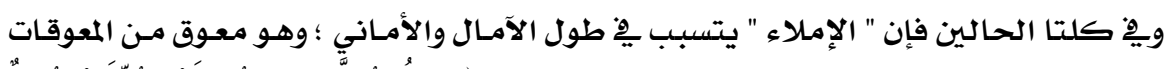

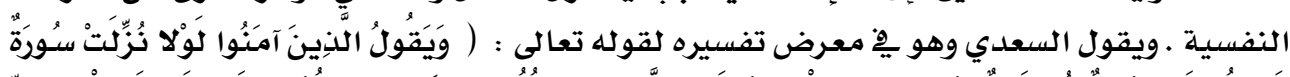

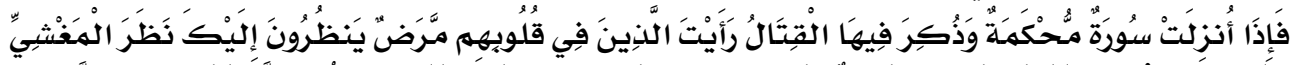

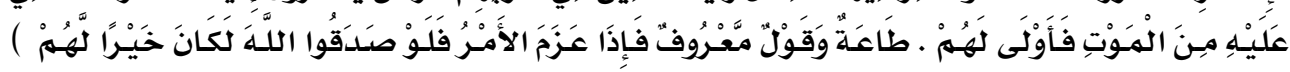

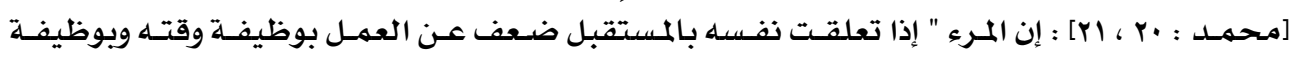

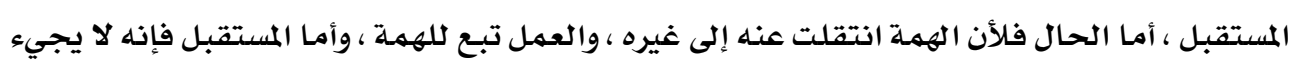

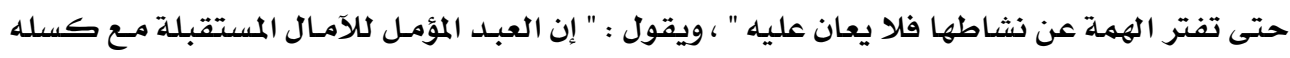

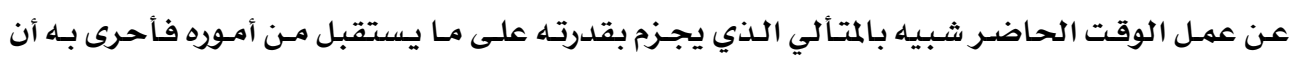

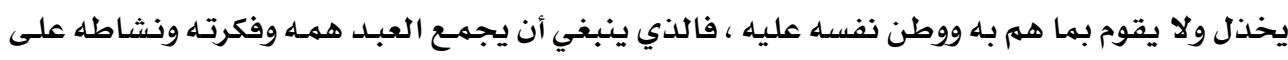

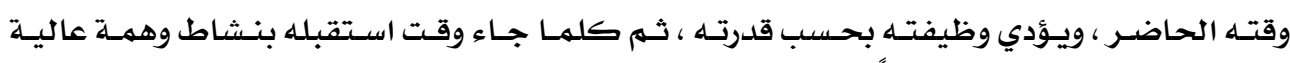

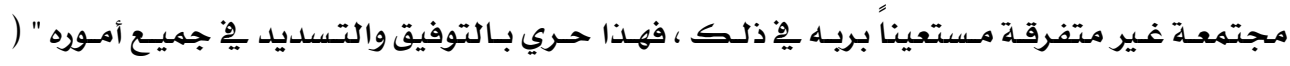

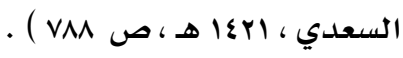
.

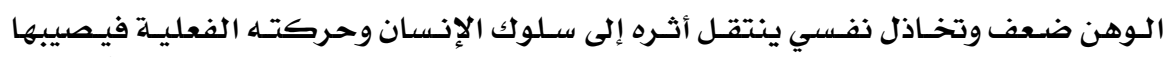

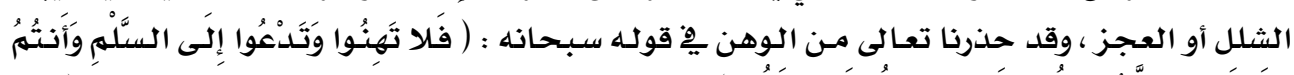

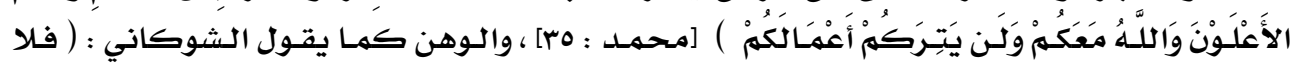

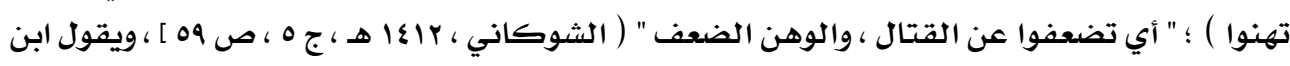

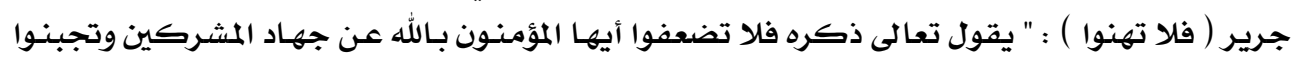

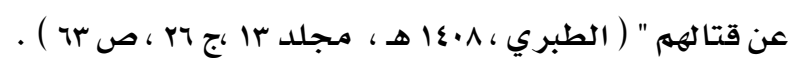

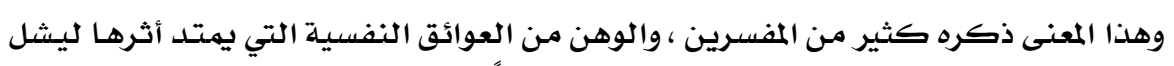

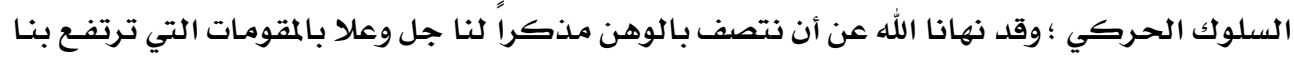

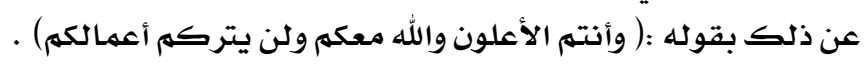




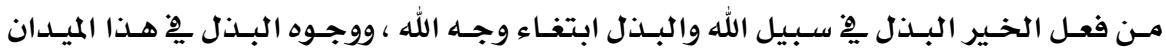

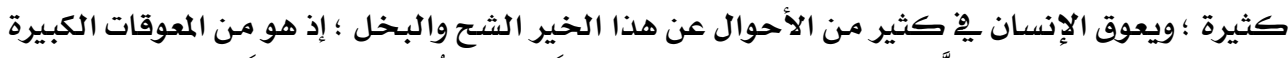

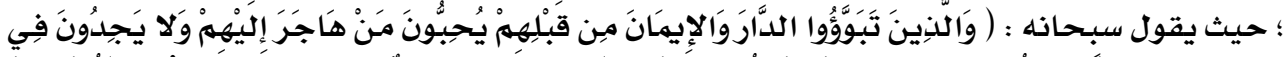

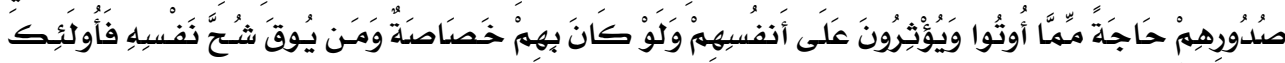

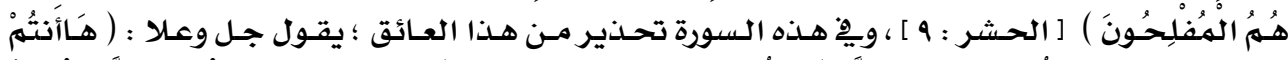

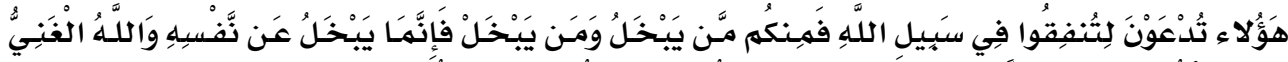

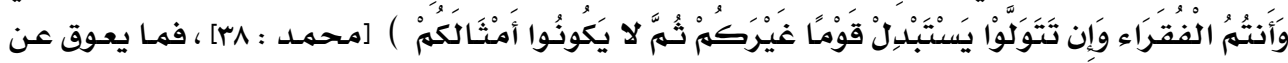

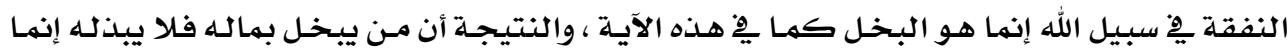

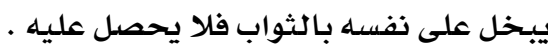

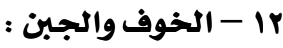

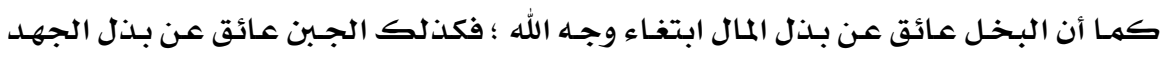

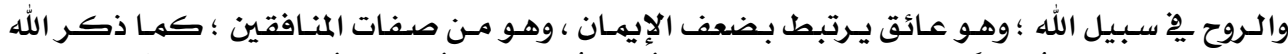

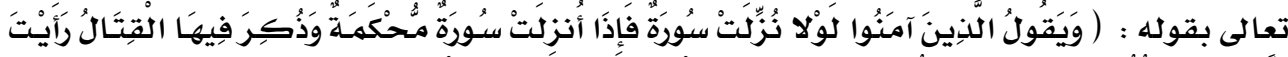

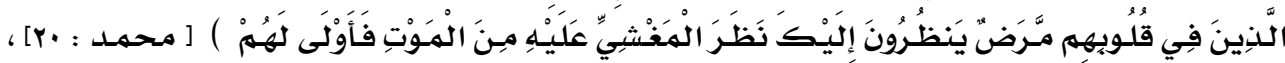

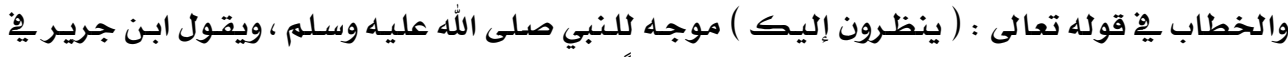

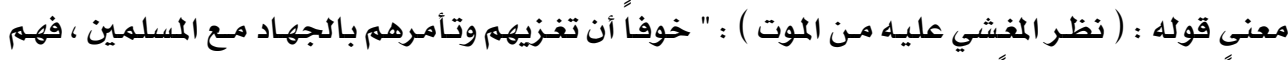

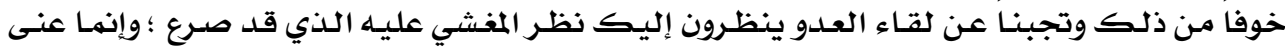

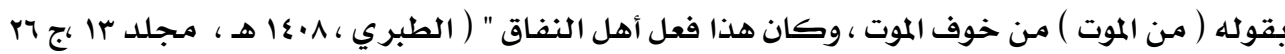

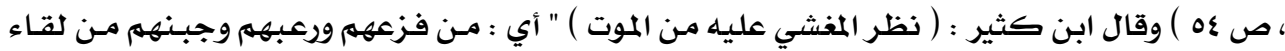

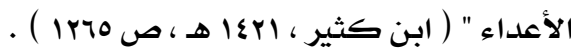

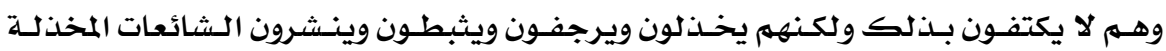

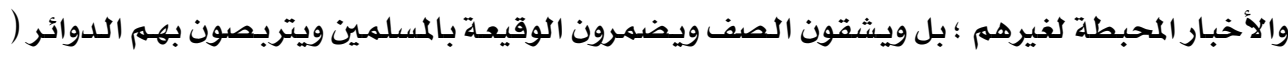

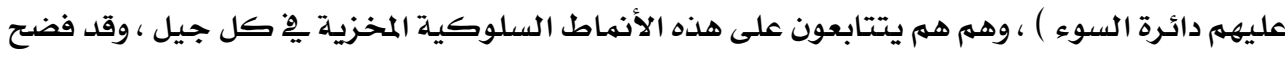

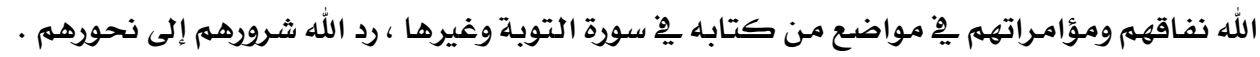

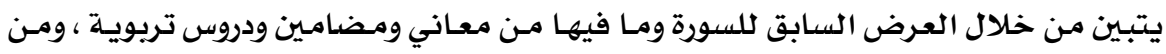

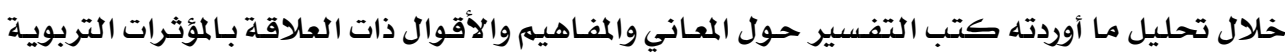
يمكن إجمال أهم النتائج المستخلصة من ذلك أنس فيما يأتي :

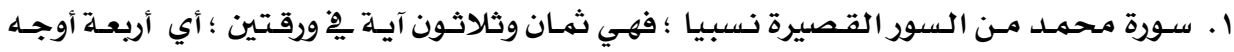

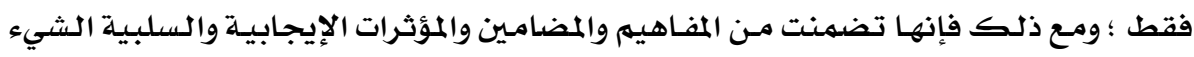




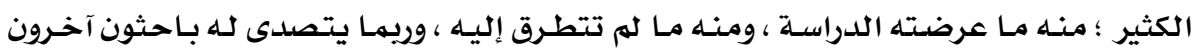

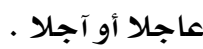

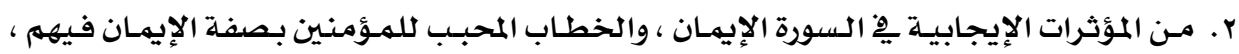

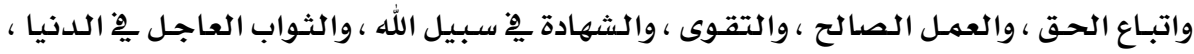

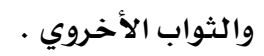

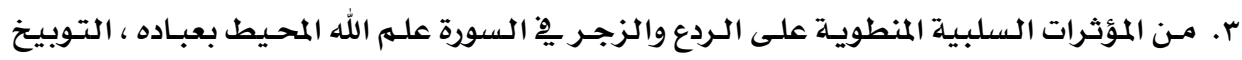

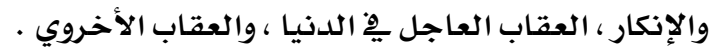

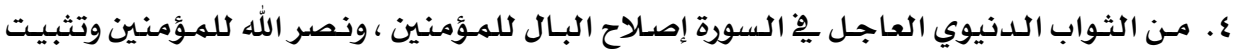

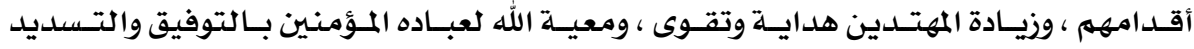

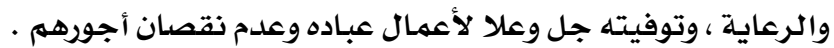

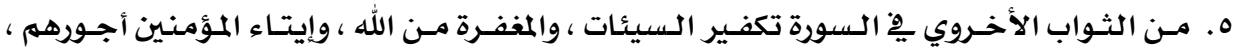
والجنة وهي الحافز الأكبر ، وما فيها من أنواع العناع النعيم .

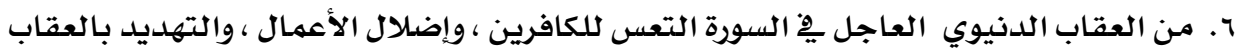

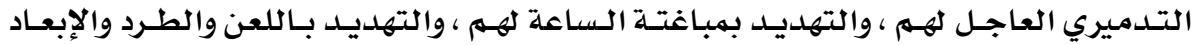

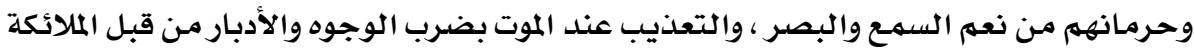

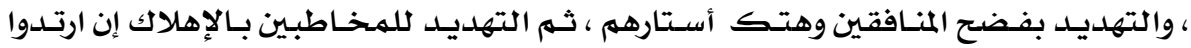

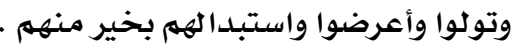

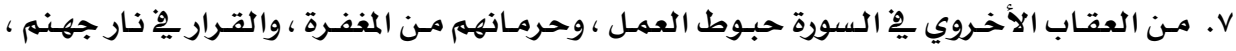

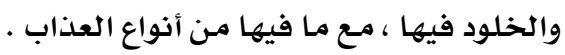

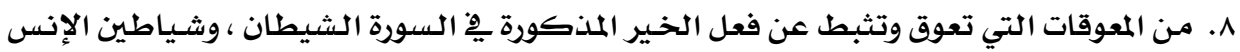

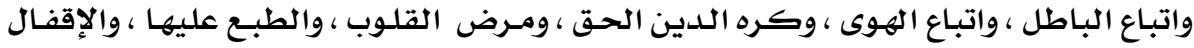

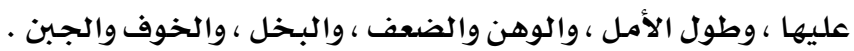

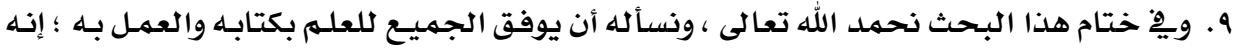
ولي ذلك والقادر عليه ، وصلى الله وسله على نبينا محمد وعلى آلى آله وصحبه أجمعين . 


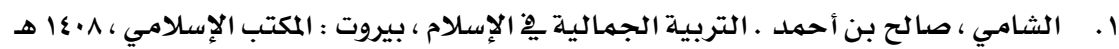

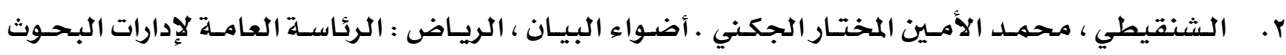

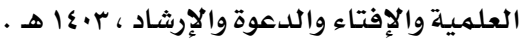

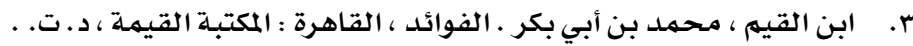

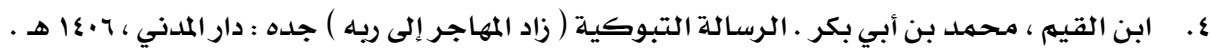

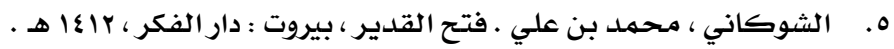

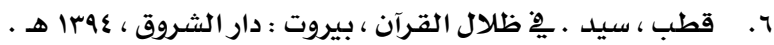

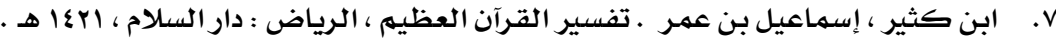

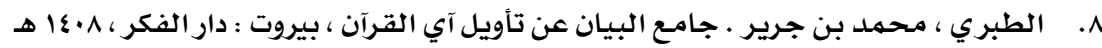

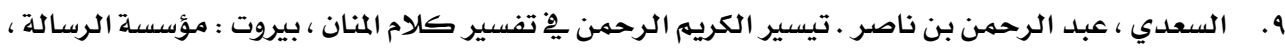
. $ه|\leqslant r|$

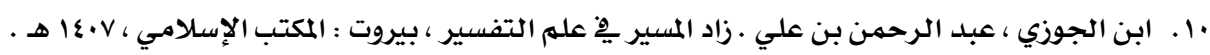

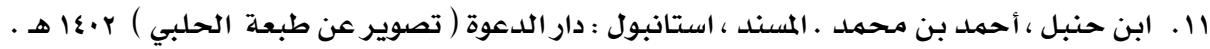

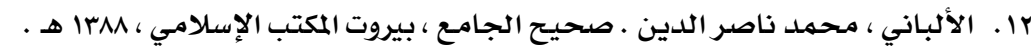

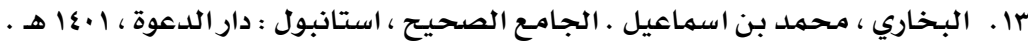

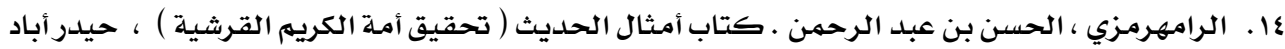

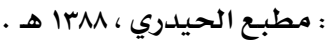

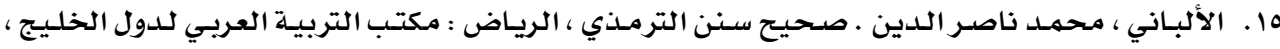
. $\Delta$ 17 . الألباني ، محمـد ناصـر الدين . صـحيح سـنن ابن ماجـة ، الريـاض : مكتب التربية العربـي لـدول الخليجج ، . 1 \&.V

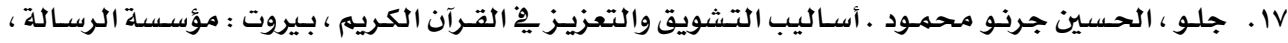
. ها

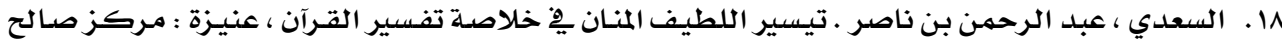

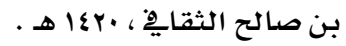

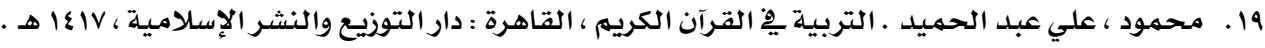

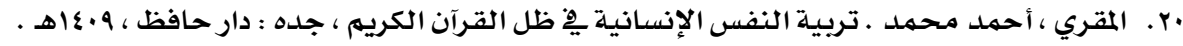

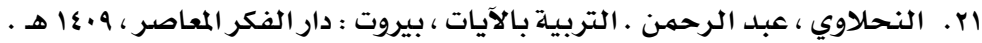

